\title{
Source rock characteristics of the Early Cretaceous Garau and Gadvan formations in the western Zagros Basin-southwest Iran
}

\author{
Mehdi Kobraei $^{1} \cdot$ Ahmad Reza Rabbani $^{1}\left[\right.$ Farid Taati $^{2}$
}

Received: 3 November 2016/Accepted: 29 May 2017/Published online: 15 June 2017

(C) The Author(s) 2017. This article is an open access publication

\begin{abstract}
Cretaceous source succession in the Zagros Basin comprises the Garau, Gadvan, and Kazhdumi formations, which have probably generated most of the oil and associated gas in the region. In the following study, the generation potential as well as maturity, molecular, and isotopic characteristics of the Early Cretaceous source rocks (Garau and Gadvan formations) in southwest Iran were investigated. One hundred and forty core and cutting samples of Early Cretaceous sediments were obtained from 24 wells in 12 oil fields from the northern Dezful Embayment and Abadan plain. Geochemical measurements such as Rock-Eval pyrolysis, vitrinite reflectance, GC, GC-MS, and isotopic studies were conducted on selected samples. The results have shown that the Gadvan Formation, with an average TOC of $0.65 \mathrm{wt} \%$ and $\mathrm{HI}$ values of $122 \mathrm{mgHC} / \mathrm{g}$ TOC, can be classified as poor source rock, while the Garau Formation, with TOC and HI values of up to $5.72 \mathrm{wt} \%$ and $413 \mathrm{mgHC} / \mathrm{g}$ TOC, respectively, can be considered as having good to excellent source potential. Kerogen in the Gadvan Formation belongs to Type III/II, while kerogen in the Garau Formation belongs to Type II. Samples from the Gadvan Formation are at the beginning of oil generation, while the current maturity of the Garau samples is already in the peak oil generation stage. Maturity in the studied samples increases eastward toward the Dezful Embayment. GC, GC-MS and isotopic values for the Gadvan Formation
\end{abstract}

Ahmad Reza Rabbani

rabbani@aut.ac.ir

1 Faculty of Petroleum Engineering, AmirKabir University of Technology, Tehran, Iran

2 Geology Department, NIOC, Khazar Exploration and Production Company, Tehran, Iran indicate high land plant contribution, low maturity, and oxic to sub-oxic depositional environment of the organic matter. In contrast, the Garau Formation shows an advanced level of maturity and marine depositional environment. Considering the results of this study, the Garau Formation, with excellent production potential and a high level of maturity, can be regarded as a source of a huge amount of oil and gas in the region.

Keywords Source rock - Production potential - Early Cretaceous · Garau Formation · Gadvan Formation · Zagros Basin

\section{Introduction}

The Khami and Bangestan Groups are the main Cretaceous oil producers in southwestern Iran. Among the Cretaceous succession, the Kazhdumi, Gadvan and Garau formations have source rock characteristics and contributed to the generation of most of the oil and associated gas reserves already discovered. The Albian Kazhdumi Formation has been investigated in a number of previous studies (Bordenave and Burwood 1990; Bordenave and Huc 1995; Rabbani and Bagheri Tirtashi 2010; Alizadeh et al. 2012; Mashhadi et al. 2014; Mashhadi and Rabbani 2015). Early Cretaceous source intervals in southern Iran comprise the Gadvan and Garau formations, which are the main subject of this study. There are some previous studies on the Gadvan and Garau formations (or their time equivalent) in the Zagros Basin (Abeed et al. 2011; Rabbani et al. 2013), but all of them have been done outside of the studied area.

The purpose of present study is to investigate the potential source rock characteristics of the Early Cretaceous succession in the oilfields of southwestern Iran. In

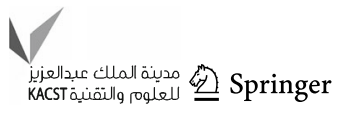


order to characterize the quantity, quality, and maturity of organic matter in the studied intervals, Rock-Eval pyrolysis and vitrinite reflectance were conducted, and additional data, such as GC, GC-MS and isotope analysis, were used to interpret the depositional environment and oilsource correlation.

\section{Geological setting}

The available data suggest that the central Iranian block was part of the Arabian Platform and belonged to the Gondwana supercontinent during the Precambrian and early Paleozoic (Stocklin 1974). The breakup between the Arabian platform and the Central Iranian block at the end of the Triassic caused the formation of the Neo-Tethys Ocean, which expanded during the Jurassic and the Early Cretaceous as a result of the seafloor spreading (Stocklin 1974). The northeast margin of the Arabian platform was passive, with the seafloor spreading during the end of the Triassic to end of the Middle Cretaceous period. During the same period, deep marine sediments, i.e., radiolarite or micritic limestone, were deposited at the northeast edge of the Arabian platform (Muris 1980). After the collision of the Arabian and Eurasian plates (including the Iranian block), the Neo-Tethys Ocean shrank as a result of a complex succession of subductions (Sepehr and Cosgrove 2004). This tectonic change caused the area to become active, and compressional tectonic events occurred from the Cenomanian.

The Dezful Embayment, which belongs geologically to the northern part of the Arabian plate is a tectonic feature at the southwestern edge of the Zagros Basin (Fig. 1) and contains Iran's major oil fields. The Dezful Embayment is bounded by three main tectonic elements, namely the E-W trending flexure zone (the Balaroud fault) and a "mountain front" flexure with a NW-SE trend in the northern part. To the east and southeast, the Dezful Embayment is bounded by a complex zone of faults and flexures having a N-S trend (Kazerun-Qatar fault) (Falcon 1967; Motiei 1995; Alavi 2007).

The Abadan Plain is a structural unit limited to the NE by the Susangerd-Ab-e Teymur-Mansuri Zagros trend, to the south by the Persian Gulf, and to the west by the IranIraq border (Fig. 1). The generally $\mathrm{N}-\mathrm{S}$ trending pre-Zagros anticlines of the Abadan Plain are not exposed in outcrop, but occur in the subsurface. The Abadan Plain was part of the Mesopotamian Depression during the Jurassic and Early Cretaceous (Jassim and Goff 2006; Abeed et al. 2011; Aqrawi et al. 2010).

A global sea-level rise followed the end of Jurassic regression during the Valanginian. As the sea-level rose, shallow-water limestone was widely deposited on the platform area during the Early Cretaceous, i.e., southwest Lurestan, southern Iraq, the Abadan Plain, and the wide Fars area. The Early Cretaceous morphology of the sedimentary basin was formed after the deposition of the Upper Jurassic evaporites in the Gotnia Formation.

Subsequent to the deposition of these evaporites, the southern part of Khuzestan was covered by a deeper water depression that extended in the Lurestan. In this depression, sedimentation of fine carbonate mud, together with organic matter, prevailed (Fig. 2). Euxinic conditions favorable for the preservation of these organic-rich sediments were also present, making way for the development of a suitable source rock (James and Wynd 1965).

The Garau Formation consists of five units in the Abadan plain area. The bottom unit consists of dark gray to black carbonaceous shale and dark argillaceous pyritic limestone (James and Wynd 1965). Overlying this is dark gray limestone with carbonaceous shale. Above this is gray to brown shale, and above that is limestone with black nodules. The upper part of the formation is alternating gray shale with shaley limestone, and glauconitic sandy limestone and sandy marls in the uppermost part. Almost all of the Garau Formation is considered to have been deposited under a low-energy anoxic environment, and it has excellent source rock potential, mostly in the lower part. The age of the Garau Formation ranges from Valanginian to Coniacian (Fig. 2). Limestone sequences of the Sulaiy and Yamama formations in Saudi Arabia/ Iraq, the Minagish Formation in Kuwait are the time equivalents of the Garau Formation (James and Wynd 1965; Aqrawi et al. 2010).

The Gadvan Formation (Fig. 2) was deposited during the Barremian in generally shallow oxic environment (James and Wynd 1965). However, the environment remained dis-oxic in the Lurestan and $\mathrm{S}-\mathrm{W}$ Dezful Embayment (Bordenave and Huc 1995). In the Abadan Plain and in most of the Dezful Embayment, the Gadvan Formation is dominated by brownish-yellow marl and argillaceous limestone (Kent et al. 1951; Fakour et al. 2010).

\section{Method and materials}

During this study, 140 core and cutting samples from Early Cretaceous sediments were obtained from 24 wells in 12 oil fields from northern Dezful Embayment and Abadan Plain (locations are shown in Fig. 1). The samples were selected from the Gadvan (Barremian) and Garau (Early Cretaceous) formations using gamma ray logs and binocular microscopes to avoid caving and contamination (Bordenave and Huc 1995). 


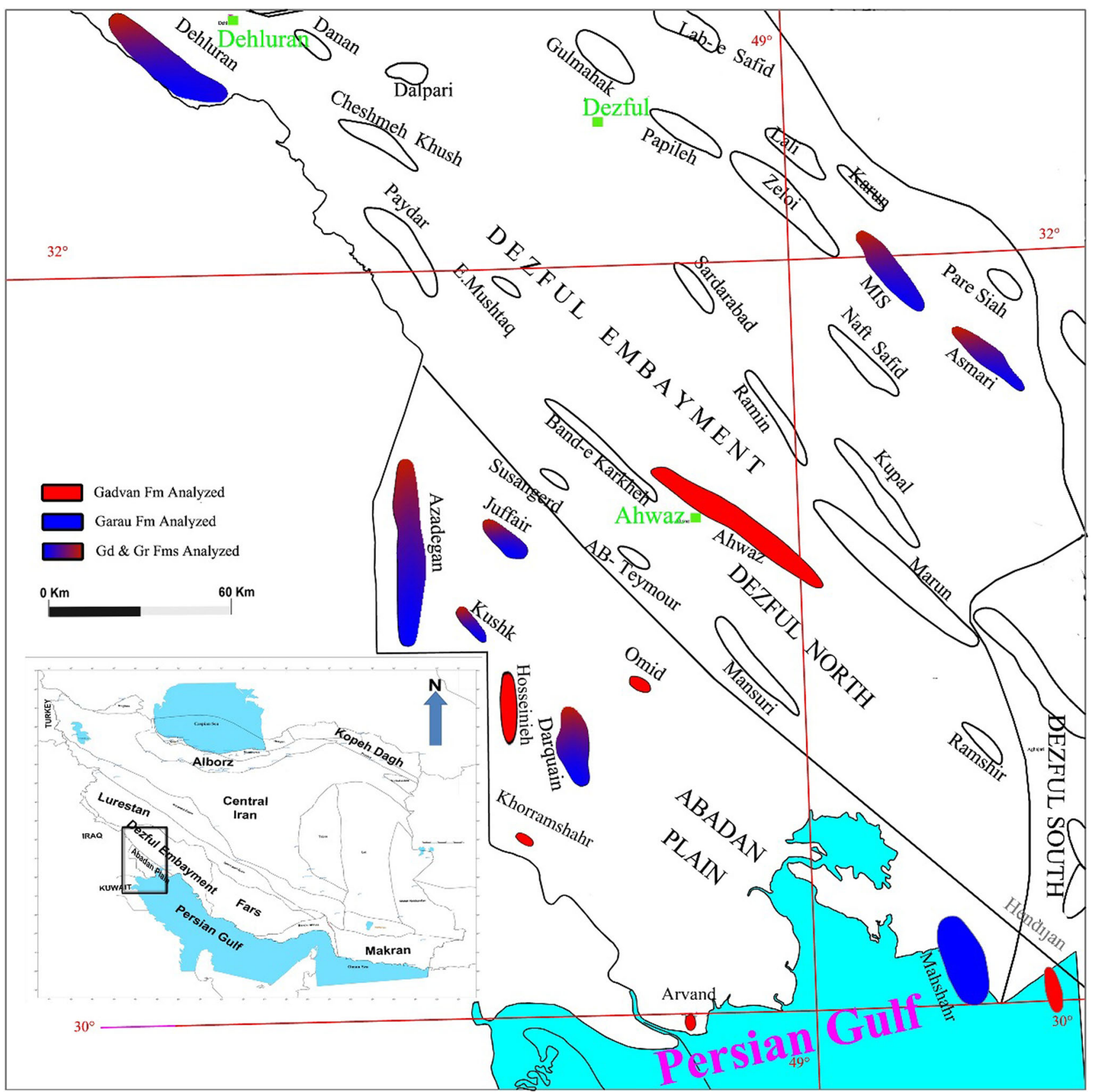

Fig. 1 Location map of the studied area and oil fields in the Zagros Basin with main tectonic boundaries. Studied samples are indicated by different colors. Modified after Abdollahie Fard et al. (2006), Bordenave and Hegre (2010), Abeed et al. (2011), Zeinalzadeh et al. (2015)

\section{Rock-Eval pyrolysis and vitrinite reflectance}

The first step in the geochemical study of petroleum systems in an area is to characterize the quantity, quality, and maturity of the source rocks. The most widely used method to identify the generation potential of source rock is RockEval pyrolysis (Espitalié et al. 1977). After some treatment to remove synthetic contamination such as mica, iron junk, nut shell, and drilling mud additives, samples were ground and homogenized.
Rock-Eval apparatus yields the following information for rock samples: Total organic carbon (TOC), S1 hydrocarbon already present in the sample, S2 remaining potential, S3 oxygen content, and $T_{\max }$ related to the maturity (Espitalié et al. 1977; Tissot and Welte 1984; Espitalié and Bordenave 1993; Peters and Cassa 1994). Table 1 shows the Rock-Eval measures and calculation parameters for studied samples.

Twenty-eight samples were selected for measuring vitrinite reflectance according to the Rock-Eval pyrolysis results. Reflectance was measured using Zeiss Axioplan II 
Fig. 2 Stratigraphic chart of the studied area in southwest Iran. The main sources are indicated by two stars and the marginal ones by one star. After Bordenave and Hegre (2010)

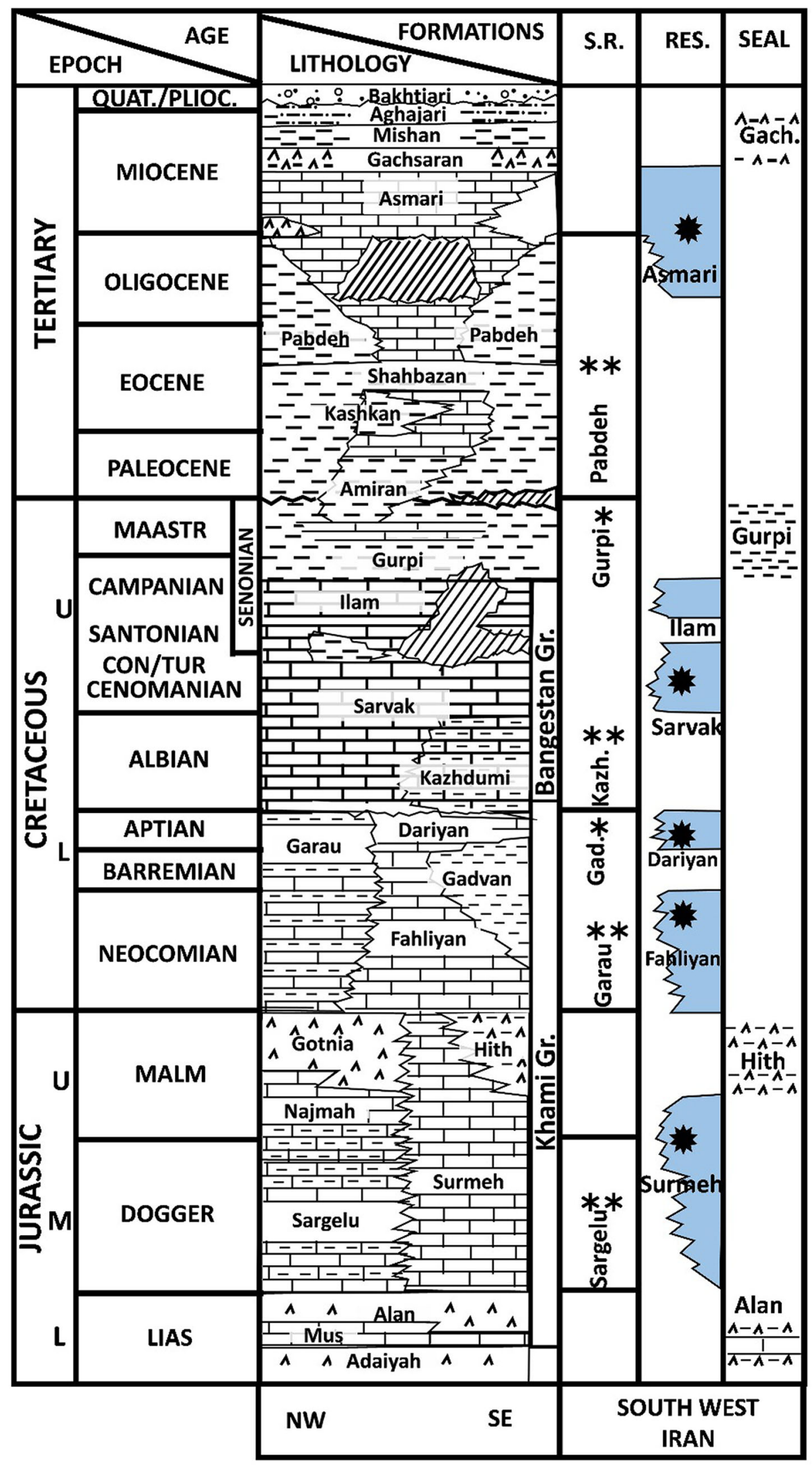


Table 1 Rock-Eval pyrolysis result of the studied samples

\begin{tabular}{|c|c|c|c|c|c|c|c|c|c|c|c|}
\hline Field name & Formation & $\begin{array}{l}\text { Depth } \\
\text { (m) }\end{array}$ & $\begin{array}{l}\text { Sample } \\
\text { type }\end{array}$ & $\begin{array}{l}\text { TOC } \\
\text { (wt } \%)\end{array}$ & $\begin{array}{l}\text { S1 } \\
\text { (mg HC/g rock) }\end{array}$ & $\begin{array}{l}\mathrm{S} 2 \\
\text { (mg HC/g rock) }\end{array}$ & $\begin{array}{l}\mathrm{S} 3 \\
\text { (mg HC/g rock) }\end{array}$ & $T_{\max }\left({ }^{\circ} \mathrm{C}\right)$ & $\begin{array}{l}\text { HI } \\
\text { (mg HC/g TOC) }\end{array}$ & OI & PI \\
\hline Arvand & Gadvan & 3650 & Cutting & 0.33 & 0.11 & 0.23 & 1.06 & 431 & 69 & 325 & 0.32 \\
\hline Arvand & Gadvan & 3680 & Cutting & 0.24 & 0.04 & 0.14 & 0.6 & 431 & 58 & 247 & 0.24 \\
\hline Arvand & Gadvan & 3710 & Cutting & 0.54 & 0.14 & 0.58 & 1.72 & 437 & 107 & 318 & 0.2 \\
\hline Arvand & Gadvan & 3820 & Cutting & 0.63 & 0.14 & 0.46 & 1.9 & 435 & 74 & 301 & 0.23 \\
\hline Azadegan & Gadvan & 3725 & Cutting & 1.31 & 8.53 & 6.48 & 0.9 & 434 & 495 & 69 & 0.57 \\
\hline Azadegan & Gadvan & 3755 & Cutting & 1.84 & 8.78 & 3.6 & 0.81 & 431 & 196 & 44 & 0.71 \\
\hline Azadegan & Gadvan & 3895 & Cutting & 1.39 & 3.16 & 3.14 & 0.93 & 429 & 226 & 67 & 0.5 \\
\hline Azadegan & Gadvan & 3915 & Cutting & 1.66 & 5.17 & 4.97 & 0.92 & 432 & 299 & 56 & 0.51 \\
\hline Azadegan & Gadvan & 4055 & Cutting & 2.54 & 13.19 & 6.6 & 1.17 & 430 & 260 & 46 & 0.67 \\
\hline Azadegan & Gadvan & 4085 & Cutting & 2.18 & 9.39 & 5.95 & 0.7 & 437 & 273 & 32 & 0.61 \\
\hline Azadegan & Gadvan & 3562 & Core & 0.86 & 0.4 & 1.23 & 1.52 & 434 & 143 & 177 & 0.25 \\
\hline Azadegan & Gadvan & 3790 & Core & 0.9 & 0.36 & 1.05 & 2 & 433 & 117 & 222 & 0.26 \\
\hline Azadegan & Gadvan & 3855 & Core & 0.87 & 0.4 & 0.62 & 2.39 & 429 & 71 & 275 & 0.4 \\
\hline Azadegan & Gadvan & 3930 & Core & 0.91 & 0.37 & 0.81 & 2.32 & 432 & 89 & 255 & 0.31 \\
\hline Azadegan & Gadvan & 3980 & Core & 0.43 & 0.21 & 0.42 & 1.95 & 429 & 98 & 453 & 0.33 \\
\hline Azadegan & Gadvan & 3780 & Cutting & 1.57 & 1.03 & 3.19 & 2.83 & 434 & 203 & 180 & 0.24 \\
\hline Azadegan & Gadvan & 3860 & Cutting & 0.68 & 0.29 & 0.38 & 2 & 431 & 56 & 294 & 0.44 \\
\hline Azadegan & Gadvan & 3930 & Cutting & 0.66 & 0.27 & 0.47 & 2.02 & 429 & 71 & 306 & 0.37 \\
\hline Azadegan & Gadvan & 3820 & Cutting & 0.63 & 0.21 & 1.29 & 0.84 & 429 & 205 & 133 & 0.14 \\
\hline Azadegan & Gadvan & 3842 & Cutting & 0.48 & 0.18 & 0.52 & 1.84 & 431 & 108 & 383 & 0.25 \\
\hline Azadegan & Gadvan & 3890 & Cutting & 0.59 & 0.13 & 1.07 & 0.72 & 432 & 181 & 122 & 0.11 \\
\hline Azadegan & Gadvan & 3950 & Cutting & 0.6 & 0.28 & 0.63 & 1.62 & 428 & 105 & 270 & 0.3 \\
\hline Azadegan & Gadvan & 3725 & Core & 0.43 & 0.06 & 0.22 & 0.96 & 432 & 51 & 223 & 0.2 \\
\hline Azadegan & Gadvan & 3855 & Core & 0.61 & 0.13 & 0.5 & 1.99 & 431 & 82 & 326 & 0.21 \\
\hline Azadegan & Gadvan & 3900 & Core & 0.44 & 0.1 & 0.35 & 2.17 & 433 & 80 & 493 & 0.22 \\
\hline Ahwaz & Gadvan & 3690 & Core & 0.62 & 0.2 & 0.52 & 3.31 & 430 & 84 & 534 & 0.27 \\
\hline Ahwaz & Gadvan & 3750 & Core & 1.35 & 0.32 & 2 & 2.12 & 440 & 148 & 157 & 0.14 \\
\hline Ahwaz & Gadvan & 3770 & Core & 0.73 & 0.23 & 0.67 & 2.5 & 434 & 92 & 342 & 0.25 \\
\hline Darquain & Gadvan & 3814 & Cutting & 0.43 & 0.1 & 0.38 & 0.51 & 436 & 88 & 119 & 0.22 \\
\hline Darquain & Gadvan & 3848 & Cutting & 0.45 & 0.08 & 0.32 & 0.48 & 438 & 71 & 107 & 0.2 \\
\hline Darquain & Gadvan & 3887 & Cutting & 0.29 & 0.04 & 0.15 & 0.55 & 438 & 52 & 190 & 0.21 \\
\hline Darquain & Gadvan & 3915 & Cutting & 0.35 & 0.07 & 0.25 & 0.48 & 437 & 71 & 137 & 0.23 \\
\hline Darquain & Gadvan & 3933 & Cutting & 0.38 & 0.09 & 0.29 & 0.65 & 436 & 76 & 171 & 0.23 \\
\hline Darquain & Gadvan & 3966 & Cutting & 0.56 & 0.14 & 0.49 & 0.73 & 441 & 88 & 130 & 0.22 \\
\hline Darquain & Gadvan & 4018 & Cutting & 0.38 & 0.4 & 0.45 & 0.68 & 433 & 118 & 179 & 0.47 \\
\hline Darquain & Gadvan & 4079 & Cutting & 0.32 & 0.11 & 0.26 & 0.58 & 437 & 81 & 181 & 0.29 \\
\hline Darquain & Gadvan & 3955 & Cutting & 0.79 & 0.6 & 0.81 & 1.4 & 434 & 103 & 177 & 0.43 \\
\hline Darquain & Gadvan & 4205 & Cutting & 1.92 & 4.52 & 6.8 & 0.76 & 435 & 355 & 40 & 0.4 \\
\hline Darquain & Gadvan & 3621 & Core & 0.28 & 0.18 & 0.66 & 0.59 & 430 & 236 & 211 & 0.21 \\
\hline Darquain & Gadvan & 3650 & Core & 0.22 & 0.21 & 0.46 & 0.56 & 431 & 209 & 255 & 0.31 \\
\hline Hendijan & Gadvan & 3435 & Cutting & 1.6 & 0.15 & 2.68 & 2.14 & 431 & 168 & 134 & 0.05 \\
\hline Hendijan & Gadvan & 3510 & Cutting & 0.61 & 0.04 & 0.59 & 0.83 & 429 & 97 & 136 & 0.06 \\
\hline Hosseinieh & Gadvan & 3750 & Cutting & 0.37 & 0.06 & 0.26 & 1 & 437 & 70 & 270 & 0.19 \\
\hline Hosseinieh & Gadvan & 3790 & Cutting & 0.46 & 0.1 & 0.18 & 1.06 & 434 & 40 & 229 & 0.35 \\
\hline Hosseinieh & Gadvan & 3820 & Cutting & 0.56 & 0.08 & 0.25 & 2.43 & 433 & 45 & 432 & 0.23 \\
\hline Hosseinieh & Gadvan & 3840 & Cutting & 0.26 & 0.05 & 0.13 & 0.94 & 430 & 48 & 360 & 0.29 \\
\hline Hosseinieh & Gadvan & 3865 & Cutting & 1.32 & 0.72 & 3.73 & 0.53 & 436 & 283 & 40 & 0.16 \\
\hline
\end{tabular}


Table 1 continued

\begin{tabular}{|c|c|c|c|c|c|c|c|c|c|c|c|}
\hline Field name & Formation & $\begin{array}{l}\text { Depth } \\
(\mathrm{m})\end{array}$ & $\begin{array}{l}\text { Sample } \\
\text { type }\end{array}$ & $\begin{array}{l}\text { TOC } \\
\text { (wt } \%)\end{array}$ & $\begin{array}{l}\mathrm{S} 1 \\
\text { (mg HC/g rock) }\end{array}$ & $\begin{array}{l}\mathrm{S} 2 \\
\text { (mg HC/g rock) }\end{array}$ & $\begin{array}{l}\mathrm{S} 3 \\
\text { (mg HC/g rock) }\end{array}$ & $T_{\max }\left({ }^{\circ} \mathrm{C}\right)$ & $\begin{array}{l}\mathrm{HI} \\
\text { (mg HC/g TOC) }\end{array}$ & OI & PI \\
\hline Hosseinieh & Gadvan & 4010 & Cutting & 0.46 & 0.15 & 0.31 & 2.44 & 431 & 67 & 528 & 0.32 \\
\hline Hosseinieh & Gadvan & 4130 & Cutting & 0.74 & 0.17 & 0.37 & 2.54 & 428 & 49 & 341 & 0.31 \\
\hline Hosseinieh & Gadvan & 3910 & Cutting & 0.92 & 0.94 & 1.46 & 2.27 & 431 & 159 & 247 & 0.39 \\
\hline Hosseinieh & Gadvan & 3931 & Cutting & 1.26 & 1.44 & 1.74 & 2.42 & 432 & 138 & 192 & 0.45 \\
\hline Juffair & Gadvan & 4200 & Core & 0.64 & 0.3 & 1.06 & 0.9 & 429 & 165 & 139 & 0.22 \\
\hline Juffair & Gadvan & 4285 & Core & 0.72 & 0.14 & 1.26 & 0.58 & 436 & 175 & 81 & 0.1 \\
\hline Juffair & Gadvan & 4320 & Core & 0.91 & 0.21 & 2.24 & 1.77 & 431 & 246 & 194 & 0.08 \\
\hline Khorramshahr & Gadvan & 3523 & Cutting & 0.28 & 0.14 & 0.42 & 0.61 & 436 & 150 & 218 & 0.25 \\
\hline Khorramshahr & Gadvan & 3539 & Cutting & 0.56 & 0.19 & 0.82 & 0.73 & 438 & 146 & 130 & 0.18 \\
\hline Khorramshahr & Gadvan & 3568 & Cutting & 0.5 & 0.24 & 0.52 & 1 & 430 & 104 & 200 & 0.31 \\
\hline Khorramshahr & Gadvan & 3597 & Cutting & 0.71 & 0.19 & 0.74 & 0.88 & 436 & 104 & 124 & 0.2 \\
\hline Khorramshahr & Gadvan & 3627 & Cutting & 0.44 & 0.24 & 0.68 & 0.7 & 437 & 155 & 159 & 0.26 \\
\hline Khorramshahr & Gadvan & 3651 & Cutting & 0.72 & 0.18 & 0.89 & 1.44 & 436 & 124 & 200 & 0.17 \\
\hline Khorramshahr & Gadvan & 3694 & Cutting & 0.47 & 0.16 & 0.51 & 1.35 & 433 & 109 & 287 & 0.25 \\
\hline Khorramshahr & Gadvan & 3725 & Cutting & 0.63 & 0.26 & 0.49 & 1.66 & 430 & 78 & 263 & 0.35 \\
\hline Khorramshahr & Gadvan & 3749 & Cutting & 0.52 & 0.16 & 0.81 & 1.07 & 437 & 156 & 206 & 0.17 \\
\hline Khorramshahr & Gadvan & 3813 & Cutting & 0.83 & 0.19 & 1.14 & 1 & 438 & 137 & 120 & 0.14 \\
\hline Kushk & Gadvan & 3925 & Cutting & 0.44 & 0.33 & 0.64 & 1.4 & 436 & 145 & 318 & 0.34 \\
\hline Kushk & Gadvan & 3950 & Cutting & 0.69 & 0.23 & 0.69 & 1.35 & 434 & 100 & 196 & 0.25 \\
\hline Omid & Gadvan & 4430 & Cutting & 0.34 & 0.32 & 0.31 & 0.68 & 431 & 91 & 200 & 0.5 \\
\hline Omid & Gadvan & 4525 & Cutting & 1.23 & 0.83 & 1.42 & 3.04 & 430 & 115 & 247 & 0.37 \\
\hline Azadegan & Garau & 3835 & Cutting & 1.09 & 0.63 & 1.35 & 3.4 & 433 & 124 & 312 & 0.32 \\
\hline Azadegan & Garau & 3905 & Cutting & 2.16 & 8.91 & 7.03 & 1.01 & 435 & 325 & 47 & 0.56 \\
\hline Azadegan & Garau & 4033 & Cutting & 0.73 & 0.2 & 0.44 & 2.38 & 424 & 60 & 326 & 0.32 \\
\hline Azadegan & Garau & 4095 & Cutting & 0.27 & 0.16 & 0.34 & 1.1 & 416 & 126 & 407 & 0.31 \\
\hline Azadegan & Garau & 4135 & Cutting & 0.6 & 1.1 & 1.48 & 1.55 & 434 & 247 & 258 & 0.43 \\
\hline Azadegan & Garau & 4215 & Cutting & 0.31 & 0.24 & 0.34 & 0.94 & 424 & 110 & 303 & 0.42 \\
\hline Azadegan & Garau & 4346 & Cutting & 0.76 & 1.91 & 3.6 & 1.76 & 432 & 474 & 232 & 0.35 \\
\hline Juffair & Garau & 4170 & Cutting & 0.69 & 1.13 & 0.84 & 1.92 & 434 & 122 & 278 & 0.57 \\
\hline Juffair & Garau & 4664 & Cutting & 1.26 & 0.91 & 2.86 & 0.73 & 434 & 227 & 58 & 0.24 \\
\hline Juffair & Garau & 4666 & Cutting & 2.4 & 0.8 & 9.33 & 1.24 & 442 & 389 & 52 & 0.08 \\
\hline Juffair & Garau & 4706 & Cutting & 3.24 & 1.15 & 8.23 & 1.88 & 443 & 254 & 58 & 0.12 \\
\hline Juffair & Garau & 4714 & Cutting & 3.17 & 5.03 & 4.71 & 1.03 & 434 & 149 & 32 & 0.52 \\
\hline Juffair & Garau & 4756 & Cutting & 2.98 & 2.4 & 5.09 & 1.17 & 433 & 171 & 39 & 0.32 \\
\hline Juffair & Garau & 4776 & Cutting & 2.48 & 1.07 & 5.55 & 1.17 & 442 & 224 & 47 & 0.16 \\
\hline Juffair & Garau & 4860 & Cutting & 1.52 & 4.08 & 4.64 & 0.76 & 442 & 305 & 50 & 0.47 \\
\hline Juffair & Garau & 4895 & Cutting & 1.11 & 4.58 & 3.68 & 0.73 & 444 & 331 & 66 & 0.55 \\
\hline Juffair & Garau & 4906 & Cutting & 3.85 & 7.98 & 8.95 & 1.63 & 440 & 232 & 42 & 0.47 \\
\hline Juffair & Garau & 4920 & Cutting & 0.76 & 3 & 2.18 & 0.72 & 443 & 287 & 95 & 0.58 \\
\hline Juffair & Garau & 4935 & Cutting & 0.42 & 1.21 & 1.16 & 0.58 & 441 & 276 & 139 & 0.51 \\
\hline Juffair & Garau & 4980 & Cutting & 0.43 & 1.18 & 1.08 & 0.39 & 443 & 253 & 92 & 0.52 \\
\hline Juffair & Garau & 4990 & Cutting & 0.66 & 2.18 & 1.5 & 0.83 & 442 & 227 & 126 & 0.59 \\
\hline Juffair & Garau & 5015 & Cutting & 0.64 & 2.44 & 2.05 & 0.5 & 443 & 321 & 78 & 0.54 \\
\hline Juffair & Garau & 5105 & Cutting & 2.46 & 9.15 & 6.69 & 1.61 & 445 & 272 & 66 & 0.58 \\
\hline Juffair & Garau & 5120 & Cutting & 2.56 & 7.24 & 8.22 & 1.69 & 453 & 321 & 66 & 0.47 \\
\hline Juffair & Garau & 5200 & Cutting & 4.16 & 9.85 & 8.53 & 1.55 & 449 & 205 & 37 & 0.54 \\
\hline Juffair & Garau & 5345 & Cutting & 1.91 & 6.97 & 5.62 & 2.32 & 445 & 294 & 121 & 0.55 \\
\hline
\end{tabular}


Table 1 continued

\begin{tabular}{|c|c|c|c|c|c|c|c|c|c|c|c|}
\hline Field name & Formation & $\begin{array}{l}\text { Depth } \\
(\mathrm{m})\end{array}$ & $\begin{array}{l}\text { Sample } \\
\text { type }\end{array}$ & $\begin{array}{l}\text { TOC } \\
(\mathrm{wt} \%)\end{array}$ & $\begin{array}{l}\text { S1 } \\
\text { (mg HC/g rock) }\end{array}$ & $\begin{array}{l}\mathrm{S} 2 \\
\text { (mg HC/g rock) }\end{array}$ & $\begin{array}{l}\mathrm{S} 3 \\
\text { (mg HC/g rock) }\end{array}$ & $T_{\max }\left({ }^{\circ} \mathrm{C}\right)$ & $\begin{array}{l}\text { HI } \\
\text { (mg HC/g TOC) }\end{array}$ & OI & PI \\
\hline Juffair & Garau & 5360 & Cutting & 1.78 & 8.11 & 4.49 & 2.25 & 437 & 252 & 126 & 0.64 \\
\hline Juffair & Garau & 5375 & Cutting & 1.2 & 5.1 & 3.83 & 1.48 & 442 & 320 & 124 & 0.57 \\
\hline Mahshahr & Garau & 4510 & Cutting & 1.56 & 9.91 & 3.53 & 0.72 & 441 & 226 & 46 & 0.74 \\
\hline Mahshahr & Garau & 4680 & Cutting & 0.97 & 6.11 & 2.19 & 0.61 & 445 & 226 & 63 & 0.74 \\
\hline Mahshahr & Garau & 5020 & Cutting & 1.63 & 8.92 & 3.6 & 0.93 & 434 & 221 & 57 & 0.71 \\
\hline Mahshahr & Garau & 5080 & Cutting & 1.45 & 7.89 & 4.23 & 0.75 & 440 & 292 & 52 & 0.65 \\
\hline Darquain & Garau & 3960 & Cutting & 0.49 & 1.84 & 1.08 & 0.34 & 438 & 220 & 69 & 0.63 \\
\hline Darquain & Garau & 3985 & Cutting & 1.02 & 4.75 & 2.87 & 0.64 & 440 & 281 & 63 & 0.62 \\
\hline Darquain & Garau & 4638 & Cutting & 0.72 & 1.95 & 3.21 & 0.37 & 433 & 445 & 52 & 0.38 \\
\hline Darquain & Garau & 4650 & Cutting & 1.1 & 1.07 & 2.58 & 0.47 & 438 & 234 & 43 & 0.29 \\
\hline Darquain & Garau & 4656 & Cutting & 1.25 & 2.18 & 4.22 & 0.64 & 438 & 337 & 51 & 0.34 \\
\hline Darquain & Garau & 4700 & Cutting & 2.1 & 1.7 & 2.99 & 0.61 & 439 & 142 & 29 & 0.36 \\
\hline Darquain & Garau & 4750 & Cutting & 1.87 & 1.22 & 3.15 & 0.77 & 440 & 168 & 41 & 0.28 \\
\hline Darquain & Garau & 4765 & Cutting & 0.86 & 3.21 & 1.72 & 0.59 & 441 & 200 & 69 & 0.65 \\
\hline Darquain & Garau & 4830 & Cutting & 1.52 & 1.92 & 4.21 & 0.79 & 440 & 277 & 52 & 0.31 \\
\hline Darquain & Garau & 4880 & Cutting & 1.82 & 2.22 & 3.93 & 0.71 & 439 & 217 & 39 & 0.36 \\
\hline Darquain & Garau & 4905 & Cutting & 2.22 & 2.18 & 5.85 & 0.62 & 440 & 263 & 28 & 0.27 \\
\hline Darquain & Garau & 4950 & Cutting & 0.58 & 0.63 & 0.94 & 0.41 & 438 & 162 & 70 & 0.4 \\
\hline Darquain & Garau & 4970 & Cutting & 0.62 & 0.1 & 2.25 & 0.72 & 442 & 360 & 116 & 0.04 \\
\hline Dehloran & Garau & 5117 & Cutting & 0.63 & 0.57 & 1.19 & 0.40 & 437 & 189 & 63 & 0.32 \\
\hline Dehloran & Garau & 5165 & Cutting & 0.44 & 0.48 & 1.2 & 0.15 & 440 & 273 & 34 & 0.29 \\
\hline Dehloran & Garau & 5190 & Cutting & 0.69 & 0.72 & 2.85 & 0.21 & 438 & 413 & 30 & 0.20 \\
\hline Dehloran & Garau & 5239 & Cutting & 0.73 & 0.84 & 1.86 & 0.16 & 439 & 255 & 22 & 0.31 \\
\hline Haftkel & Garau & 3300 & Cutting & 1 & 1.2 & 1.47 & 0.25 & 440 & 147 & 25 & 0.45 \\
\hline Haftkel & Garau & 3450 & Cutting & 0.98 & 0.82 & 0.99 & 0.44 & 441 & 101 & 45 & 0.45 \\
\hline Haftkel & Garau & 3580 & Cutting & 1.15 & 0.77 & 1.25 & 0.82 & 443 & 108 & 71 & 0.38 \\
\hline Haftkel & Garau & 3600 & Cutting & 1.97 & 1.2 & 2.42 & 1.04 & 444 & 123 & 53 & 0.33 \\
\hline Haftkel & Garau & 3700 & Cutting & 2.75 & 1.11 & 1.89 & 1.16 & 444 & 68 & 42 & 0.37 \\
\hline Haftkel & Garau & 3800 & Cutting & 1.42 & 0.87 & 1.25 & 0.88 & 445 & 88 & 62 & 0.41 \\
\hline Haftkel & Garau & 4050 & Cutting & 2.22 & 0.43 & 0.97 & 0.95 & 446 & 43 & 43 & 0.31 \\
\hline Haftkel & Garau & 4150 & Cutting & 1.1 & 0.65 & 1.71 & 0.62 & 448 & 155 & 56 & 0.28 \\
\hline Haftkel & Garau & 4250 & Cutting & 1.25 & 0.88 & 1.92 & 0.95 & 447 & 153 & 76 & 0.31 \\
\hline Kushk & Garau & 4502 & Cutting & 0.92 & 4.74 & 3.77 & 0.35 & 440 & 410 & 38 & 0.56 \\
\hline Kushk & Garau & 4550 & Cutting & 6.42 & 14.4 & 5.33 & 0.51 & 438 & 83 & 8 & 0.73 \\
\hline Kushk & Garau & 4624 & Cutting & 6.02 & 6.09 & 3.11 & 0.48 & 438 & 52 & 8 & 0.66 \\
\hline Kushk & Garau & 4655 & Cutting & 3.88 & 1.86 & 2.74 & 0.31 & 442 & 71 & 8 & 0.40 \\
\hline Kushk & Garau & 4695 & Cutting & 5.72 & 1.22 & 3.85 & 1.43 & 441 & 67 & 25 & 0.24 \\
\hline Kushk & Garau & 4750 & Cutting & 0.61 & 1.51 & 2.05 & 0.32 & 442 & 336 & 53 & 0.42 \\
\hline Kushk & Garau & 4810 & Cutting & 3.56 & 2.85 & 3.92 & 0.53 & 442 & 110 & 15 & 0.42 \\
\hline Kushk & Garau & 4850 & Cutting & 10.8 & 10.7 & 13.05 & 0.54 & 442 & 121 & 5 & 0.45 \\
\hline Kushk & Garau & 5100 & Cutting & 2.3 & 1.05 & 3.7 & 0.69 & 443 & 161 & 30 & 0.22 \\
\hline Kushk & Garau & 5116 & Cutting & 4.21 & 1.15 & 3.27 & 0.51 & 441 & 77 & 12 & 0.26 \\
\hline Kushk & Garau & 5152 & Cutting & 1.53 & 4.81 & 3.99 & 0.60 & 442 & 261 & 39 & 0.55 \\
\hline Kushk & Garau & 5170 & Cutting & 1.48 & 5.65 & 4.01 & 0.55 & 445 & 271 & 37 & 0.58 \\
\hline Khorramshahr & Garau & 4080 & Cutting & 0.33 & 0.29 & 0.69 & 0.9 & 441 & 209 & 273 & 0.3 \\
\hline
\end{tabular}


microscope in oil immersion following the method described by Taylor et al. (1998) and Alizadeh et al. (2012). The results are exhibited in Table 2.

\section{Complementary analysis}

According to the Rock-Eval pyrolysis results, 25 rock samples were selected for extraction, liquid and gas chromatography experiments. Gas chromatography mass spectrometry (GC-MS) and isotopic analyses were performed on 14 and 11 of the selected samples, respectively. Compoundspecific isotope measurement (GC-IRMS) was carried out on four samples from both the Gadvan and Garau formations.

Ground rock samples were extracted by Soxhlet using dichloromethane (DCM) for $24 \mathrm{~h}$; the solvent was removed by centrifuge evaporator. To fractionate the extract, a liquid column of silica gel activated by alumina was employed. Saturate, aromatic, and polar compounds were fractionated by n-hexane, benzene, and chloroform, respectively.
Gas chromatography (GC) analysis was performed by an instrument equipped with a $30 \mathrm{~m}$ DB-1 fused silica capillary column (i.d. $0.25 \mathrm{~mm} ; 0.25 \mu \mathrm{m}$ film thickness). For mass spectrometry analysis, the GC was coupled to a Finingan MAT GCQ ion trap mass spectrometer. The oven temperature was programmed from 70 to $300{ }^{\circ} \mathrm{C}$ at a rate of $4{ }^{\circ} \mathrm{C} / \mathrm{min}$, in which $15 \mathrm{~min}$ was considered as the isothermal period. The injection temperature was $275^{\circ} \mathrm{C}$ in split-less mode, and the carrier gas was helium. For calculating GC and GC-MS, a biomarker ratio peak area for each compound was considered.

For GC-IRMS analysis, in which carbon isotopic ratio is measured for specific saturated hydrocarbon, a trace GC was coupled to a Delta $\mathrm{V}$ isotope ratio mass spectrometer via a combustion interface, and a ComFlow IV unit, all ThermoFisher. At the beginning and end of each analysis, $\mathrm{CO}_{2}$ was injected for calibration. Isotopic ratios are reported with respect to the Vienna Pee Dee Belemnite (VPDB) standard.

Table 2 Vitrinite reflectance measurement results of studied samples

\begin{tabular}{|c|c|c|c|c|c|c|}
\hline Field name & Formation & Depth & $\mathrm{Ro}_{\min }$ & $\mathrm{Ro}_{\max }$ & $\mathrm{Ro}_{\text {mean }}$ & Comment \\
\hline Azadegan & Gadvan & 3940 & 0.28 & 1.29 & 0.6 & Core \\
\hline Azadegan & Gadvan & 4129 & 0.37 & 1.35 & 0.7 & Cutting \\
\hline Azadegan & Gadvan & 3757 & 0.56 & 1.11 & 0.89 & Cutting \\
\hline Azadegan & Gadvan & 3940 & 0.28 & 1.29 & 0.6 & Cutting \\
\hline Azadegan & Gadvan & 4128 & 0.37 & 1.35 & 0.7 & Cutting \\
\hline Mahshahr & Gadvan & 4400 & 0.61 & 0.73 & $?$ & Caving samples \\
\hline Mahshahr & Gadvan & 4500 & 0.45 & 1.46 & 0.9 & Cutting \\
\hline Kushk & Gadvan & 3946 & 0.48 & 0.8 & 0.7 & Cutting \\
\hline Kushk & Gadvan & 4020 & 0.48 & 0.48 & 0.53 & Caving samples \\
\hline Hosseinieh & Gadvan & 3931 & 0.57 & 0.57 & 0.67 & Cutting \\
\hline Hosseinieh & Gadvan & 3982 & 0.55 & 0.55 & 0.66 & Cutting \\
\hline Hosseinieh & Gadvan & 3903 & 0.52 & 1 & 0.66 & Cutting \\
\hline Omid & Gadvan & 4481 & 0.48 & 0.98 & 0.67 & Cutting \\
\hline Juffair & Gadvan & 4256 & 0.61 & 1.2 & 0.83 & Cutting \\
\hline Juffair & Gadvan & 4188 & 0.44 & 0.44 & 0.51 & Caving samples \\
\hline Darquain & Gadvan & 3844 & 0.32 & 0.32 & 0.40 & Caving samples \\
\hline Yadavaran & Gadvan & 3918 & 0.53 & 0.80 & 0.65 & Cutting \\
\hline Azadegan & Garau & 4430 & $?$ & $?$ & $0.7-0.9$ & Cutting \\
\hline Azadegan & Garau & 4470 & 0.85 & 0.9 & $0.7-0.9$ & Cutting \\
\hline Azadegan & Garau & 4552 & $?$ & $?$ & $0.7-0.9$ & Cutting \\
\hline Mahshahr & Garau & 5100 & 0.52 & 0.59 & $?$ & Caving samples \\
\hline Mahshahr & Garau & 4900 & 0.54 & 1.21 & $?$ & Caving samples \\
\hline Kushk & Garau & 4850 & 0.845 & 1.441 & 1.013 & Cutting \\
\hline Ahwaz & Garau & 4370 & 0.39 & 0.39 & 0.47 & Caving samples \\
\hline Darquain & Garau & 4700 & 0.875 & 1.231 & 1.011 & Cutting \\
\hline Darquain & Garau & 4470 & 0.71 & 0.71 & 0.80 & Cutting \\
\hline Darquain & Garau & 4790 & 0.70 & 0.70 & 0.81 & Cutting \\
\hline Darquain & Garau & 4810 & 0.72 & 0.72 & 0.84 & Cutting \\
\hline
\end{tabular}



TOC, showing production potential of the samples
Fig. 3 Plot of $\mathrm{S} 1+\mathrm{S} 2$ versus
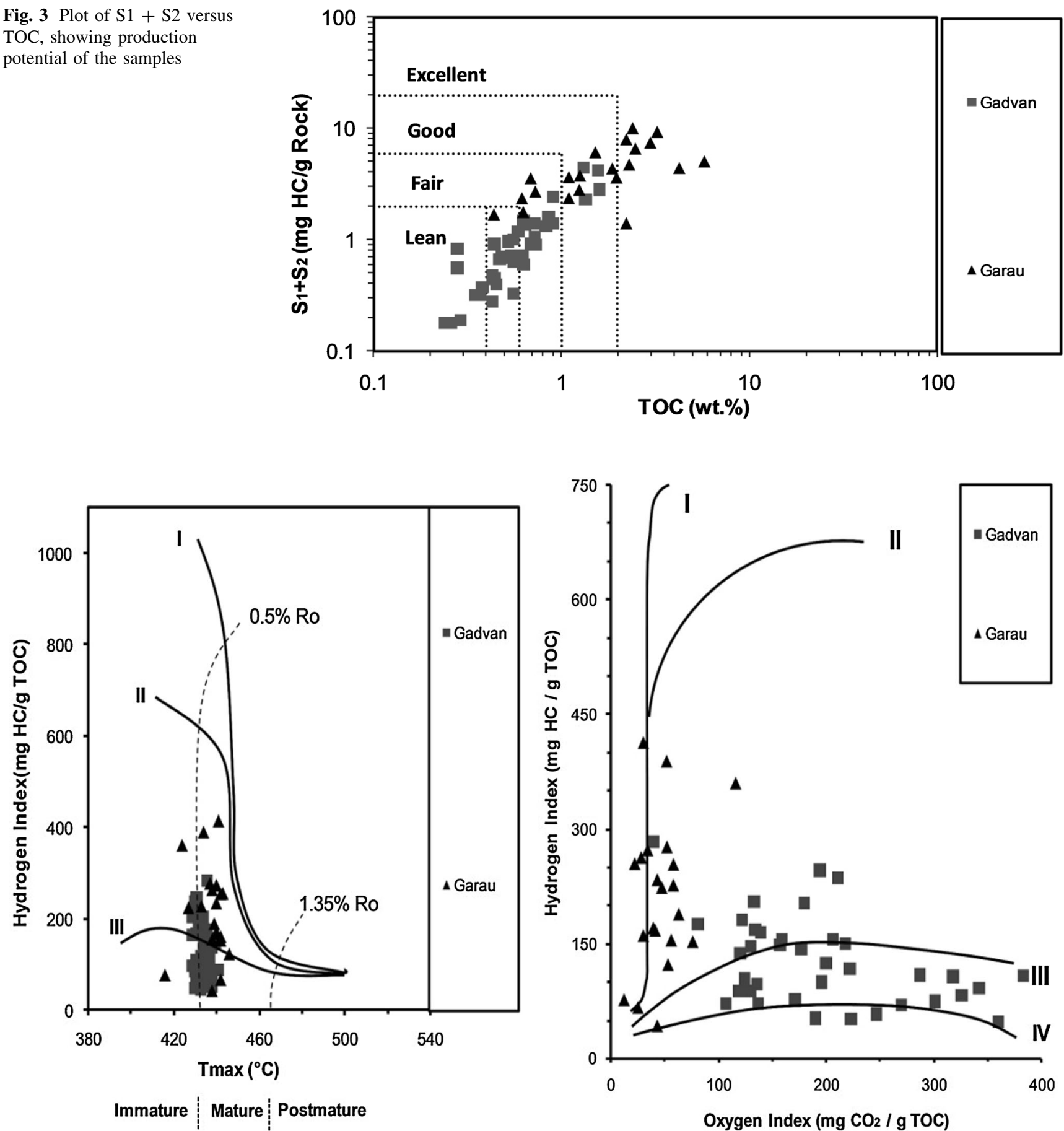

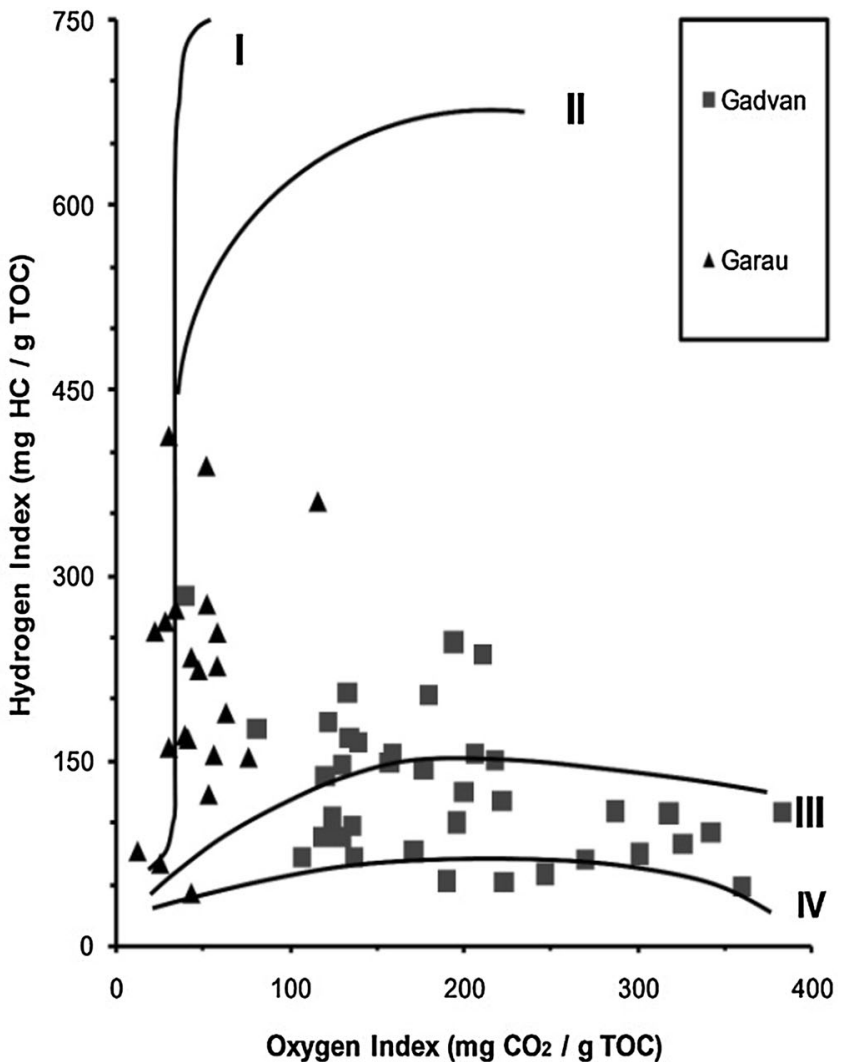

Fig. 4 Plot of HI versus $T_{\max }$ (left) and OI (right), showing maturity and kerogen type of studied samples

\section{Result and discussion}

\section{Rock-Eval and vitrinite reflectance}

The total organic carbon content of the Gadvan Formation varies from 0.25 to $1.6 \mathrm{wt} \%$. The average TOC in this formation is $0.65 \mathrm{wt} \%$ (Table 1) which is considered as poor potential source rock (Hunt 1996). Cutting samples from Azadegan show significant pollution from migrating hydrocarbons, as shown by their $\mathrm{S} 1$ values which are higher than their S2 values, for a maturity lower than $430{ }^{\circ} \mathrm{C} T_{\max }$. A similar conclusion can be made for the Darquain $4205 \mathrm{~m}$ sample. Therefore, the results of Rock-Eval analyses of these polluted samples are not discussed further. 


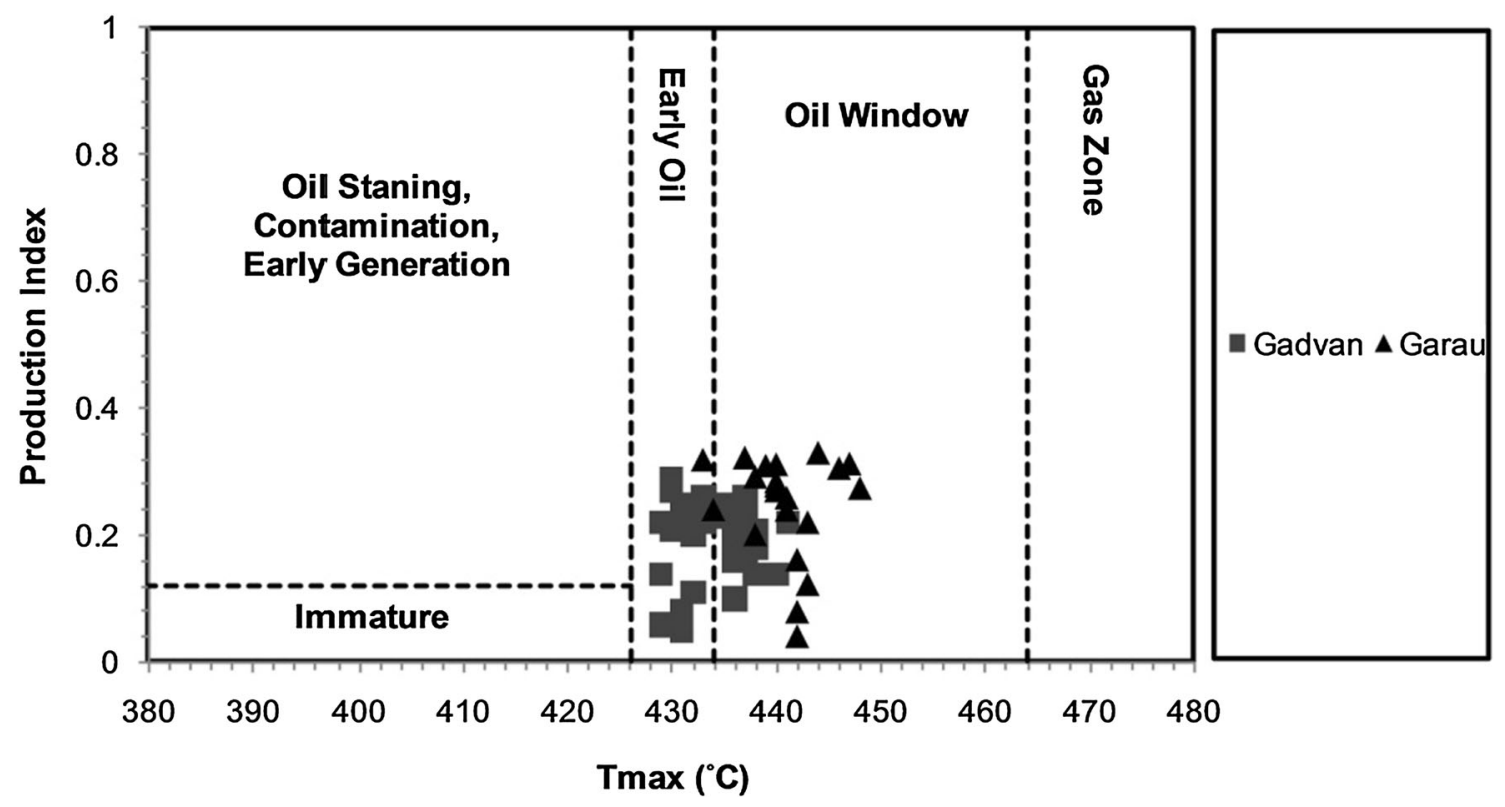

Fig. 5 Plot of PI versus $T_{\max }$, showing maturity of the studied samples
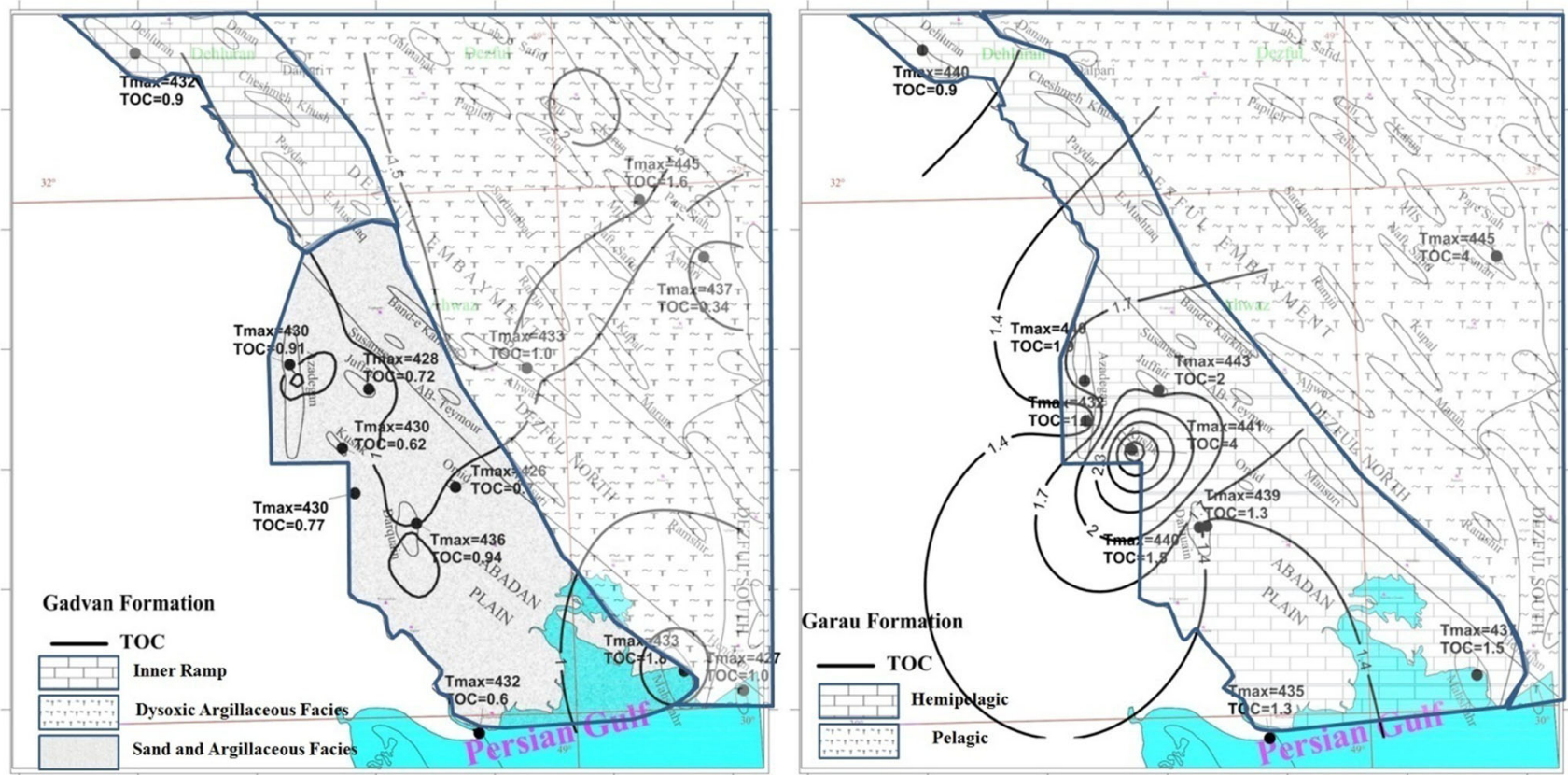

Fig. 6 Depositional environment and average TOC contour map of the Gadvan (left) and Garau (right) formations. Average $T_{\max }$ in the well location are indicated for each field. After Bordenave and Huc (1995)

In the Garau Formation, present time TOC ranges from 0.27 up to $5.72 \%$, with an average of $1.76 \%$ (Table 1 ). This value is consistent with good to very good source potential (Peters and Cassa 1994). According to paleogeographic maps, the depocenter of the Garau Formation is located in the Dezful Embayment (east of the Ahwaz oilfield) and in the Lurestan Basin (Bordenave and Hegre 2010).
The S2 peak in Rock-Eval indicates the current ability of the sample to produce hydrocarbon. In the studied samples, the present time S2 values of the Gadvan and Garau formations range $0.13-3.75$ and $0.97-9.33 \mathrm{mgHC} / \mathrm{g}$ Rock, respectively. The average values of the present time hydrogen index (HI) are 122 and $213 \mathrm{mgHC} / \mathrm{g}$ TOC in the Gadvan and Garau formations, respectively. Regarding the 

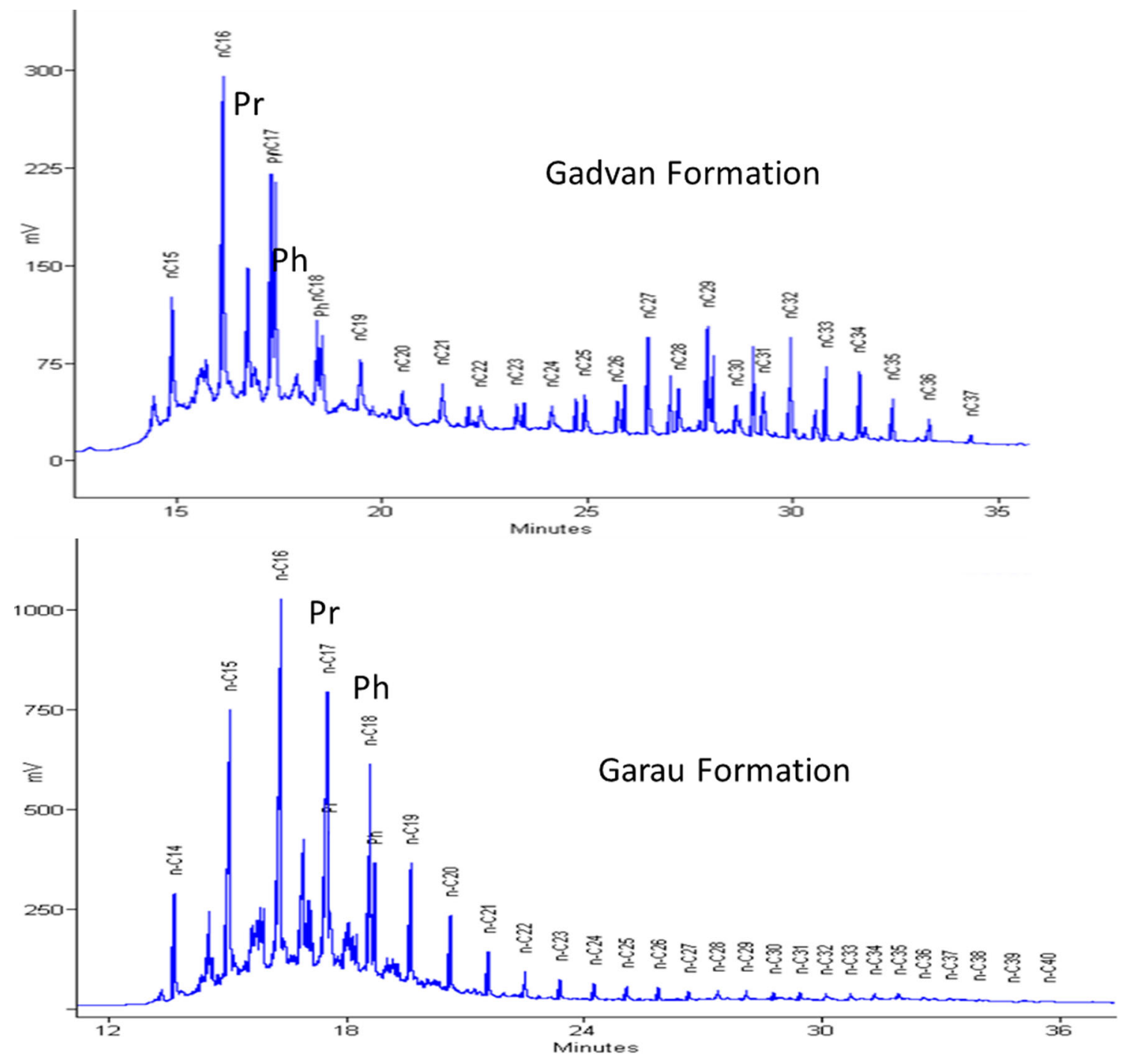

Fig. 7 GC-SAT chromatograms for the selected studied sample of the Gadvan and Garau formations indicate n-alkanes as well as Pr and Ph. GC profile of the Gadvan Formation shows a binary envelope while in the Garau Formation, an unimodal profile can be seen

plot in Fig. 3, it can be concluded that the Gadvan is a marginal source rock. In contrast, it is noteworthy that Garau samples are already close to the peak of oil expulsion window ( $T_{\max }$ in the $440-450{ }^{\circ} \mathrm{C}$ range). Therefore, initial values of both $\mathrm{S} 2$ and $\mathrm{HI}$ of Garau samples could have been much higher, even double the current values. Then the Garau Formation could be classified as very good to excellent source rock.

The hydrogen index (HI) is plotted versus the oxygen index (OI) and $T_{\max }$ values in Fig. 4 in order to identify the kerogen type of the studied samples. According to these diagrams, the kerogen of the Gadvan Formation is Type III, and in contrast, the Garau Formation contains kerogen belonging to Type II. Abeed et al. (2011), using visual kerogen studies together with the elemental analysis, reported kerogen Type II-S for the Sulaiy Formation (time equivalent of Garau Formation).
Rock sample maturities were determined on the basis of $T_{\max }$, PI, and vitrinite reflectance. In the Gadvan Formation, $T_{\max }$ values range between 430 and $441{ }^{\circ} \mathrm{C}$, with an average of $433{ }^{\circ} \mathrm{C}$. Vitrinite reflectance was measured for 17 samples and yielded approximately $0.67 \%$. According to plot of PI versus $T_{\max }$ in Fig. 5, as well as vitrinite reflectance measurements, the maturity of the organic matter in the Gadvan Formation can be regarded as being, at the most, at the beginning stage of oil generation. In the studied area, toward the northeast and the Dezful Embayment, the $T_{\max }$ values and maturity of the Gadvan Formation increase from $430{ }^{\circ} \mathrm{C}$ in the Abadan Plain to more than $440{ }^{\circ} \mathrm{C}$ in the northern Dezful Embayment, which is consistent with the increasing depth (Fig. 6). It should be considered that maturity measurements have been done on the samples from exploration wells which are drilled at the 
Table 3 Result of liquid chromatography and GC-FID for Gadvan and Garau formations

\begin{tabular}{|c|c|c|c|c|c|c|c|c|c|c|c|c|}
\hline Field name & Formation & Depth & Sat $\%$ & Aro $\%$ & Pol\% & $\mathrm{Pr} / \mathrm{Ph}$ & $\mathrm{Pr} / \mathrm{nC}_{17}$ & $\mathrm{Ph} / \mathrm{nC}_{18}$ & CPI & $\mathrm{nC}_{17} /\left(\mathrm{nC}_{17}+\mathrm{nC}_{27}\right)$ & $\mathrm{nC}_{18} /\left(\mathrm{nC}_{18}+\mathrm{nC}_{28}\right)$ & TAR \\
\hline Juffair & Gadvan & 4200 & 31.29 & 21.79 & 27.93 & 0.74 & 0.35 & 0.51 & 0.99 & 0.82 & 0.55 & 0.31 \\
\hline Khorramshahr & Gadvan & 3815 & 39.31 & 8.42 & 52.27 & 1.02 & 0.47 & 0.63 & 1.10 & 0.89 & 0.63 & 0.12 \\
\hline Azadegan & Gadvan & 3785 & 30.56 & 13.1 & 56.34 & 0.46 & 0.42 & 0.82 & 1.01 & 0.94 & 0.53 & 0.07 \\
\hline Azadegan & Gadvan & 3795 & 33.02 & 9.11 & 57.87 & 1.45 & 0.55 & 0.62 & 1.09 & 0.95 & 0.63 & $?$ \\
\hline Azadegan & Gadvan & 3935 & 19.66 & 13.11 & 67.23 & 0.95 & 0.50 & 0.63 & 1.14 & 0.95 & 0.62 & $?$ \\
\hline Azadegan & Gadvan & 3755 & 53.91 & 8.71 & 37.38 & 0.86 & 0.43 & 0.62 & 1.08 & 0.99 & 0.60 & 0.15 \\
\hline Azadegan & Gadvan & 3805 & 55.48 & 9.44 & 35.08 & 1.12 & 2.22 & 1.37 & 1.12 & 0.92 & 0.44 & 0.09 \\
\hline Azadegan & Gadvan & 4085 & 50.7 & 9.45 & 39.85 & 0.68 & 0.29 & 0.47 & 1.03 & 0.96 & 0.61 & 0.07 \\
\hline Azadegan & Gadvan & 4170 & 30.27 & 19.44 & 50.29 & 0.89 & 0.51 & 0.57 & 1.15 & 0.71 & 0.45 & 0.45 \\
\hline Azadegan & Gadvan & 3755 & 25.22 & 18.5 & 56.28 & 1.58 & 0.99 & 0.91 & 1.12 & 0.70 & 0.55 & 0.65 \\
\hline Ahwaz & Gadvan & 3710 & 12.88 & 10.02 & 77.1 & 0.49 & 0.37 & 0.40 & 1.03 & 0.58 & 0.48 & 0.09 \\
\hline Omid & Gadvan & 4530 & 25.75 & 5.52 & 68.73 & 0.71 & 0.45 & 0.53 & 1.02 & 0.92 & 0.56 & 0.30 \\
\hline Hendijan & Gadvan & 3440 & 23.29 & 15.19 & 61.52 & 0.64 & 0.79 & 1.00 & 1.18 & 0.70 & 0.50 & 0.69 \\
\hline Darquain & Gadvan & 3955 & 26.34 & 13.63 & 60.03 & 1.12 & 0.65 & 0.75 & 0.96 & 0.98 & 0.57 & 0.04 \\
\hline Kushk & Gadvan & 3950 & 28.2 & 12.9 & 58.9 & 0.91 & 0.7 & 0.8 & 0.95 & 0.8 & 0.53 & 0.15 \\
\hline Dehloran & Garau & 5190 & 57.5 & 15.5 & 27 & 0.41 & 0.7 & 0.8 & 1.01 & 0.9 & 0.6 & 0.35 \\
\hline Dehloran & Garau & 4905 & 46 & 8.5 & 45.5 & 0.43 & 0.4 & 0.8 & 1.05 & 0.88 & 0.55 & 0.09 \\
\hline Masjed Soleyman & Garau & 3732 & 61 & 12 & 27 & 0.5 & 0.49 & 0.62 & 1.06 & 0.96 & 0.61 & 0.14 \\
\hline Haftkel & Garau & 3800 & 52 & 16 & 32 & 0.68 & 0.31 & 0.68 & 1.01 & 0.89 & 0.63 & 0.35 \\
\hline Kushk & Garau & 4810 & 46.5 & 16.5 & 37 & 0.8 & 0.4 & 0.63 & 1.08 & 0.91 & 0.68 & 0.15 \\
\hline Juffair & Garau & 5120 & 55.49 & 7.88 & 36.63 & 0.68 & 0.44 & 0.77 & 1.01 & 0.94 & 0.56 & 0.09 \\
\hline Hendijan & Garau & 3990 & 23.29 & 15.19 & 61.52 & 0.42 & 0.39 & 0.50 & 1.08 & 0.48 & 0.43 & 0.37 \\
\hline Omid & Garau & 5345 & 35.18 & 2.24 & 62.58 & 0.50 & 0.51 & 0.44 & 1.12 & 0.95 & 0.66 & 0.07 \\
\hline Azadegan & Garau & 4405 & 20.57 & 10.54 & 68.89 & 0.50 & 0.41 & 0.44 & 1.09 & 0.53 & 0.48 & 0.40 \\
\hline Azadegan & Garau & 4525 & 49.24 & 11.36 & 39.4 & 0.78 & 0.39 & 0.66 & 1.08 & 0.97 & 0.66 & 0.04 \\
\hline
\end{tabular}

$\mathrm{CPI}=2\left(\mathrm{nC}_{23}+\mathrm{C}_{25}+\mathrm{C}_{27}+\mathrm{C}_{29}\right) /\left[\mathrm{C}_{22}+2\left(\mathrm{nC}_{24}+\mathrm{C}_{26}+\mathrm{C}_{28}\right)+\mathrm{nC}_{30}\right] ; \mathrm{TAR}=\left(\mathrm{nC}_{27}+\mathrm{C}_{29}+\mathrm{C}_{31}\right) /\left(\mathrm{nC}_{15}+\mathrm{C}_{17}+\mathrm{C}_{19}\right)$

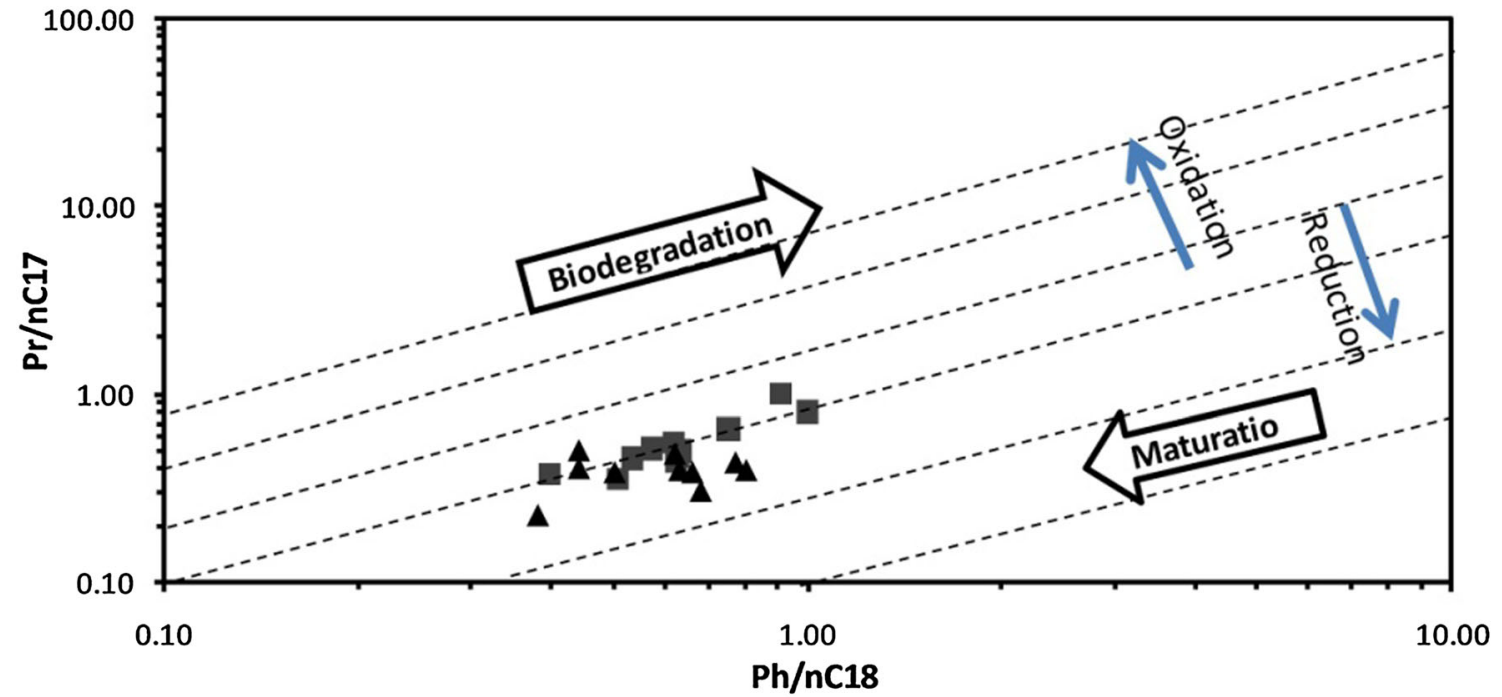

- Gadvan

$\Delta$ Garau

Fig. 8 Plot of $\mathrm{Pr} / \mathrm{nC} 17$ versus $\mathrm{Ph} / \mathrm{nC} 18$ from GC-FID, showing maturation, depositional environment, and kerogen type of organic matter 

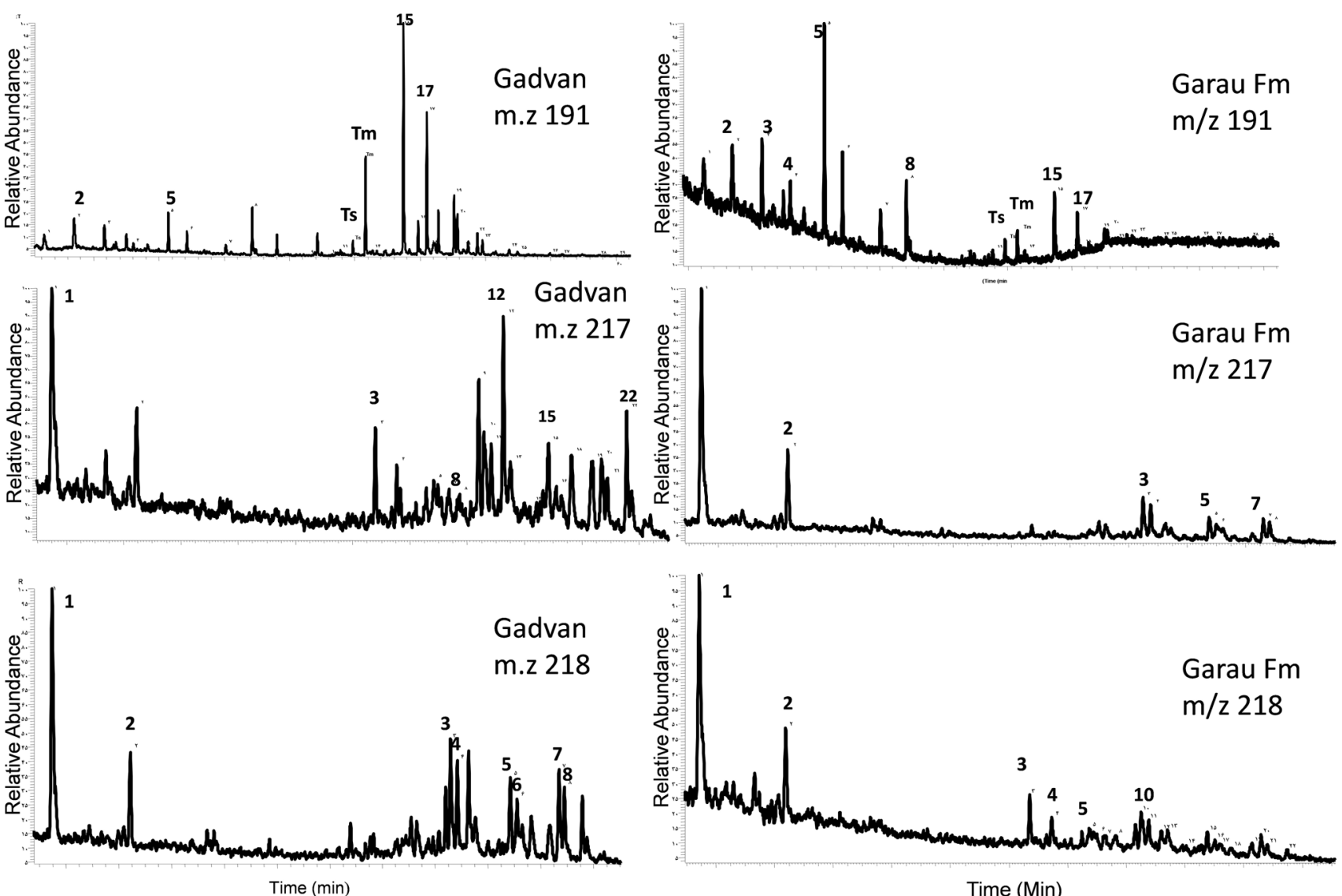

Fig. 9 Typical saturate GC-MS fragmentograms of the selected studied samples. Labeled peaks are identified in Table 4

tops (apexes) of anticlines, so in the neighboring synclines the maturity of this formation will be higher.

The Garau Formation samples are characterized by $T_{\max }$ values that range up to $453{ }^{\circ} \mathrm{C}$. Average vitrinite reflectance was measured at approximately $0.82 \%$. The plot in Fig. 5 and vitrinite reflectance measurements in Table 2 indicate organic matter maturities equal to peak oil generation in the Garau Formation, as is obvious in the $T_{\max }$ values in Fig. 6. The maturity of the Garau Formation increases toward the east of the northern part of the studied area which is consistent with the reported maturity values of its time equivalent Sulaiy Formation in southern Iraq (Abeed et al. 2011). Again it should be mentioned that the maturity of Garau Formation will be higher in the synclines and kitchen areas, because measurements are derived from samples from wells on the top of anticlines.

Most of the studied samples of the Gadvan Formation are located in the Abadan Plain. However, as shown in Fig. 6, samples located toward the Dezful Embayment show a slight increase in their TOC. Abeed et al. (2011) reported that the TOC content of the Zubair Formation (time equivalent of Gadvan) varies between 0.4 and $1 \%$. Hence, regionally, the organic matter content of the
Gadvan Formation decreases from the Dezful Embayment in Iran to the Mesopotamian Basin in Iraq.

The present time TOC content of the Garau Formation increases eastward, as indicated in the average TOC contour map in Fig. 6. In the Mesopotamian Basin west of the studied area, the TOC of the Sulaiy Formation (time equivalent of Garau) has been reported at up to $10 \%$, which means an increasing TOC westward (Abeed et al. 2011).

\section{Gas chromatography}

Two typical gas chromatograms for the Gadvan and Garau formations are shown in Fig. 7, and corresponding concentration ratios can be found in Table 3 .

The concentration of long and short chain n-alkane is significant in the Gadvan Formation, as shown in Fig. 7 (Peters and Moldowan 1993). The carbon preference index (CPI) for long chain n-alkanes and Pristane/Phytane ratios is more than $1 ; \mathrm{Pr} / \mathrm{nC}_{17}$ and $\mathrm{Ph} / \mathrm{nC}_{18}$ are less than 1 (Table 3; Fig. 8). Regarding these parameters, the high land plant contribution, low maturity, absences of biodegradation, and anoxic to sub-oxic depositional

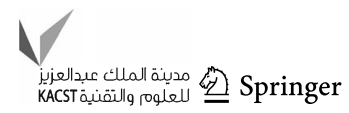


Table 4 GC-MS fragmentograms peaks identification, peaks are shown in Fig. 9

\begin{tabular}{|c|c|c|c|c|c|}
\hline Peak & $m / z$ & Compound & Peak & $\mathrm{m} / \mathrm{z}$ & Compound \\
\hline 1 & 191 & $\mathrm{C}_{19}$ tricyclic terpane & 1 & 217 & $\mathrm{C}_{21} \mathrm{H}_{36}$ pregnane \\
\hline 2 & 191 & $\mathrm{C}_{20}$ tricyclic terpane & 2 & 217 & $\mathrm{C}_{22} \mathrm{H}_{38}$ bisnorcholane \\
\hline 3 & 191 & $\mathrm{C}_{21}$ tricyclic terpane & 3 & 217 & $\mathrm{C}_{27} \mathrm{H}_{48}-\beta$ - $\alpha$-diacholestane (S) \\
\hline 4 & 191 & $\mathrm{C}_{22}$ tricyclic terpane & 4 & 217 & $\mathrm{C}_{27} \mathrm{H}_{48}-\beta$ - $\alpha$-diacholestane (R) \\
\hline 5 & 191 & $\mathrm{C}_{23}$ tricyclic terpane & 5 & 217 & $\mathrm{C}_{27} \mathrm{H}_{48}-\alpha-\beta$-diacholestane (S) \\
\hline 8 & 191 & $\mathrm{C}_{24}$ tetracyclic terpane & 6 & 217 & $\mathrm{C}_{27} \mathrm{H}_{48}-\alpha-\beta$-diacholestane (R) \\
\hline 12 & 191 & $\mathrm{C}_{27}-18 \mathrm{a}(\mathrm{H}), 21 \mathrm{~b}\left(\mathrm{H} 0-22,29,30\right.$-trisnorhopane $\left(T_{\mathrm{s}}\right)$ & 7 & 217 & $\mathrm{C}_{28} \mathrm{H}_{50}-\beta$ - $\alpha$-diacholestane (S) \\
\hline 13 & 191 & $\mathrm{C}_{27}-17 \mathrm{a}(\mathrm{H}), 21 \mathrm{~b}\left(\mathrm{H} 0-22,29,30\right.$-trisnorhopane $\left(T_{\mathrm{m}}\right)$ & 8 & 217 & $\mathrm{C}_{28} \mathrm{H}_{50^{-}} \beta$ - $\alpha$-diacholestane (R) \\
\hline 15 & 191 & $\mathrm{C}_{29}-17 \mathrm{a}(\mathrm{H}), 21 \mathrm{~b}(\mathrm{H}) 30$-norhopane & 9 & 217 & $\mathrm{C}_{28} \mathrm{H}_{50}-\beta$ - $\alpha$-diacholestane (S) \\
\hline 17 & 191 & $\mathrm{C}_{30^{-}}-17 \mathrm{a}(\mathrm{H}), 21 \mathrm{a}(\mathrm{H})$ hopane & 15 & 217 & $\mathrm{C}_{28} \mathrm{H}_{50}-\beta$ - $\beta$-cholestane (S) \\
\hline 18 & 191 & $\mathrm{C}_{30}-17 \mathrm{~b}(\mathrm{H}), 21 \mathrm{a}(\mathrm{H})$ hopane (mortane) & 16 & 217 & $\mathrm{C}_{29} \mathrm{H}_{52}-\beta-\beta$-cholestane (R) \\
\hline 19 & 191 & $\mathrm{C}_{31}-17 \mathrm{a}(\mathrm{H}), 21 \mathrm{~b}(\mathrm{H})-30$ homohopane $(22 \mathrm{~S})$ & 21 & 217 & $\mathrm{C}_{29} \mathrm{H}_{52}-\beta$ - $\beta$-cholestane (S) \\
\hline 20 & 191 & $\mathrm{C}_{31}-17 \mathrm{a}(\mathrm{H}), 21 \mathrm{~b}(\mathrm{H})-30$ homohopane $(22 \mathrm{R})$ & 22 & 217 & $\mathrm{C}_{29} \mathrm{H}_{52}-\alpha-\alpha$-cholestane (R) \\
\hline 21 & 191 & $\mathrm{C}_{30}$-Gammacerane & 5 & 218 & $\mathrm{C}_{28} \mathrm{H}_{50}-\beta-(\mathrm{R})$ \\
\hline 1 & 218 & $\mathrm{C}_{21}$-pregnane & 6 & 218 & $\mathrm{C}_{28} \mathrm{H}_{50}-\beta-(\mathrm{S})$ \\
\hline 2 & 218 & $\mathrm{C}_{22}$-pregnane & 7 & 218 & $\mathrm{C}_{29} \mathrm{H}_{52}-\beta-(\mathrm{R})$ \\
\hline 3 & 218 & $\mathrm{C}_{27} \mathrm{H}_{48}-\beta-(\mathrm{R})$ & 8 & 218 & $\mathrm{C}_{29} \mathrm{H}_{52}-\beta-(\mathrm{S})$ \\
\hline 4 & 218 & $\mathrm{C}_{27} \mathrm{H}_{48}-\beta-(\mathrm{S})$ & & & \\
\hline
\end{tabular}

Table 5 Result isotope analysis in the studied samples

\begin{tabular}{|c|c|c|c|c|c|}
\hline Field name & Formation & Whole oil $\delta^{13} \mathrm{C}$ extracted $\mathrm{HC}$ & $\begin{array}{l}\text { Saturated HC } \\
\delta^{13} \mathrm{C}(\mathrm{PDB})\end{array}$ & $\begin{array}{l}\text { Aromatic HC } \\
\delta^{13} \mathrm{C}(\mathrm{PDB})\end{array}$ & $\mathrm{CV}$ \\
\hline Kushk & Gadvan & -27.8 & -28.6 & -27.5 & -0.2 \\
\hline Darquain & Gadvan & -28.02 & -28.8 & -27.3 & 0.8 \\
\hline Azadegan & Gadvan & -28.1 & -29.2 & -27.5 & 1.2 \\
\hline Azadegan & Gadvan & -27.05 & -28.8 & -26.5 & 2.5 \\
\hline Ahwaz & Gadvan & -26.9 & -28.1 & -26.8 & 0.2 \\
\hline Hendijan & Gadvan & -25.8 & -27.4 & -25.1 & 2.0 \\
\hline Yadavaran & Gadvan & -26.7 & -27.5 & -26.0 & 0.1 \\
\hline Yadavaran & Gadvan & -26.4 & -26.7 & -26.1 & -2.0 \\
\hline Azadegan & Garau & -28.8 & -29.2 & -28.0 & 0.3 \\
\hline Azadegan & Garau & -28.1 & -29.0 & -27.9 & -0.1 \\
\hline Hendijan & Garau & -26.8 & -27.2 & -26.1 & -0.6 \\
\hline
\end{tabular}

environment for organic matter in the Gadvan Formation can be inferred (Tissot and Welte 1984; Moldowan et al. 1985).

In the Garau Formation, the unimodal GC chromatogram values as well as a high concentration of short chain n-alkanes show an advanced level of maturity. CPI values are close to 1 , the Pristane concentration is much lower than the Phytane, and, as Fig. 8 shows, the $\mathrm{Pr} / \mathrm{nC}_{17}$ and $\mathrm{Ph} / \mathrm{nC}_{18}$ are less than 1 . According to the GC parameters, high maturity, lack of biodegradation, and Type II organic matter, a strongly anoxic depositional marine environment for the Garau Formation can be inferred (Tissot and Welte 1984; Moldowan et al. 1985; Peters and Moldowan 1993).

\section{Biomarker study}

Because biomarkers are derived from biological precursor molecules in specific organisms, and because each of these organisms lives only under certain environmental conditions, it is logical to use biomarkers as indicators of those conditions (Bjorøy et al. 1992). However, any application 
Table 6 Result of GC-MS analysis for Gadvan and Garau formations

\begin{tabular}{|c|c|c|c|c|c|c|c|c|c|c|c|c|}
\hline \multirow[t]{2}{*}{ Field name } & \multirow[t]{2}{*}{ Formation } & \multirow{2}{*}{$\begin{array}{l}\text { Depth } \\
\text { (m) }\end{array}$} & \multirow{2}{*}{$\begin{array}{l}T_{\mathrm{s}} l \\
\left(T_{\mathrm{s}}+T_{\mathrm{m}}\right)\end{array}$} & \multirow{2}{*}{$\begin{array}{l}\mathrm{C}_{29} / \mathrm{C}_{30} \\
\text { Hopane }\end{array}$} & \multirow{2}{*}{$\begin{array}{l}\mathrm{C}_{31} \text { Hop 22S/ } \\
(22 \mathrm{~S}+22 \mathrm{R})\end{array}$} & \multirow{2}{*}{$\begin{array}{l}\text { Str } 2920 \mathrm{~S} / \\
(20 \mathrm{~S}+20 \mathrm{R})\end{array}$} & \multirow{2}{*}{$\begin{array}{l}\text { Str29 } \beta \beta / \\
(\beta \beta+\alpha \alpha)\end{array}$} & \multicolumn{3}{|c|}{ Regular steranes } & \multirow{2}{*}{$\begin{array}{l}\text { DBT/ } \\
\text { Phen }\end{array}$} & \multirow[t]{2}{*}{ MPI1 } \\
\hline & & & & & & & & $\mathrm{C}_{27} \%$ & $\mathrm{C}_{28} \%$ & $\mathrm{C}_{29} \%$ & & \\
\hline Kushk & Gadvan & 3950 & 0.3 & 0.95 & 0.58 & 0.41 & 0.50 & 27 & 34.00 & 39.0 & 0.7 & 0.69 \\
\hline Darquain & Gadvan & 3960 & 0.2 & 1.10 & 0.60 & 0.52 & 0.45 & 44 & 24.00 & 31.0 & 0.65 & 0.66 \\
\hline Azadegan & Gadvan & 4170 & 0.36 & 1.00 & 0.57 & 0.53 & 0.53 & 27 & 26.00 & 47.0 & 1.14 & 0.68 \\
\hline Azadegan & Gadvan & 3755 & 0.22 & 1.10 & 0.56 & 0.25 & 0.47 & 36 & 29.00 & 38.0 & 0.71 & 0.71 \\
\hline Arvand & Gadvan & 3715 & 0.14 & 1.05 & 0.58 & 0.46 & 0.43 & 42 & 24.00 & 35.0 & 0.15 & 0.51 \\
\hline Hendijan & Gadvan & 3442 & 0.3 & 1.00 & 0.48 & 0.25 & 0.30 & 37 & 27.00 & 36.0 & 0.71 & 0.62 \\
\hline $\begin{array}{l}\text { Masjed } \\
\text { Soleyman }\end{array}$ & Garau & 3732 & 0.57 & 0.87 & 0.59 & 0.5 & 0.51 & 45 & 28 & 27 & 1.77 & 0.71 \\
\hline Haftkel & Garau & 3800 & 0.5 & 1.16 & 0.59 & 0.38 & 0.48 & 30 & 35 & 35 & 3.44 & 0.64 \\
\hline Kushk & Garau & 4810 & 0.58 & 1.13 & 0.59 & 0.42 & 0.53 & 44 & 29 & 27 & 3.25 & 0.25 \\
\hline Azadegan & Garau & 4405 & 0.67 & 1.08 & 0.54 & 0.40 & 0.52 & 49 & 22 & 29 & 0.76 & 0.52 \\
\hline Azadegan & Garau & 4525 & 0.31 & 1.10 & 0.57 & 0.53 & 0.53 & 27 & 26.00 & 47.0 & 0.81 & 0.6 \\
\hline Hendijan & Garau & 3990 & 0.45 & 1.00 & 0.59 & 0.52 & 0.46 & 40 & 24.00 & 36.0 & 0.15 & 1.08 \\
\hline Dehloran & Garau & 5190 & 0.60 & 1.12 & 0.65 & 0.48 & 0.63 & 39 & 28 & 33 & 1.91 & 0.77 \\
\hline Darquain & Garau & 4905 & 0.59 & 0.92 & 0.39 & 0.4 & 0.5 & 42 & 26 & 32 & 1.25 & 0.97 \\
\hline
\end{tabular}

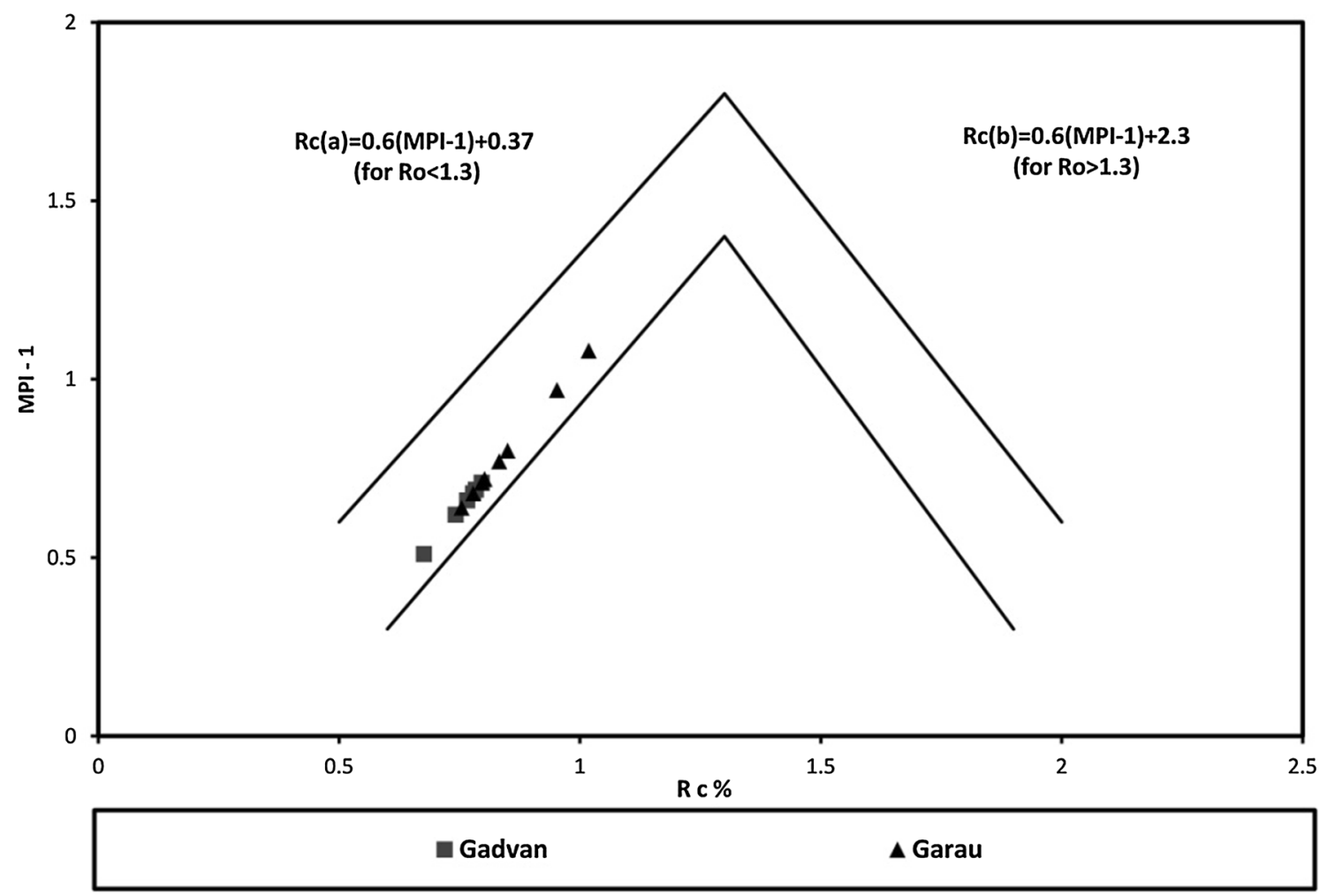

Fig. 10 Plot of MPI-1 versus calculated vitrinite reflectance in the studied samples (Peters et al. 2005) showing maturity of organic matter in the studied formations

of biomarkers for organic-facies interpretation should be made with a full awareness that organic facies (and hence biomarker distributions) can change rapidly, both vertically and laterally (Moldowan et al. 1986; Bjorøy et al. 1992). If one is working with a typical sample of cuttings material, the biomarker signature will be an average for all facies present in the sample, and thus, it will be much harder to interpret (Tables 4, 5). 
In this study, GC-MS analysis was done on saturates and aromatics fractions in 14 samples in both the Garau and Gadvan formations. Biomarker parameters for the studied samples are shown in Fig. 9 and are summarized in Table 6. Terpanes, steranes, and aromatic parameters were used to investigate the geochemical characteristics of the formations under consideration.

First, the biomarkers related to the maturity of the samples will be examined. The value of $\mathrm{C}_{31}$ homohopane $22 \mathrm{~S} /(22 \mathrm{~S}+22 \mathrm{R})$ increases with maturity, from 0 to 0.61 (Peters et al. 2005). This ratio for the Gadvan and Garau formations ranges between $0.48-0.6$ and $0.54-0.65$, suggesting an early oil window and peak oil generation, respectively (Table 6$)$. The $T_{\mathrm{s}} /\left(T_{\mathrm{s}}+T_{\mathrm{m}}\right)$ ratio in the Gadvan Formation changes from 0.14 to 0.36 , while in the Garau Formation this ratio ranges between 0.36 and 0.67, which shows again a low level of maturity in the Gadvan Formation and high level of maturity in the Garau (Peters and Moldowan 1993). In addition to maturity, the lithology of the studied samples can influence the $T_{\mathrm{s}} /\left(T_{\mathrm{s}}+T_{\mathrm{m}}\right)$ ratio; for the same maturity, the argillaceous content of the source rocks generally increases the $T_{\mathrm{s}} /\left(T_{\mathrm{s}}+T_{\mathrm{m}}\right)$ ratio (Peters et al. 2005). As most of the Garau samples are richer in carbonate, the high $T_{\mathrm{s}} /\left(T_{\mathrm{s}}+T_{\mathrm{m}}\right)$ ratios correlate to higher thermal maturity.

The $C_{29} \beta \beta /(\beta \beta+\alpha \alpha)$ sterane ratio increases from zero to nearly 0.7 (0.61-0.71 equilibrium) (Peters and Moldowan 1993). In the studied samples of the Gadvan and Garau formations, this ratio ranges between $0.3-0.53$ and $0.46-0.63$, which implies early and peak oil generation window, respectively (Table 6; Fig. 9). The average ratio of $5 \alpha(\mathrm{H}), 14 \alpha(\mathrm{H}), 17 \alpha(\mathrm{H}) \quad \mathrm{C}_{29} \quad$ and steranes 20S/ $(20 \mathrm{~S}+20 \mathrm{R})$ is 0.4 and 0.45 in the Gadvan and Garau formations, respectively.

Aromatic biomarkers are more resistive to temperature than are saturate ones (Peters et al. 2005). In this study, MPI-1 was measured for the rock samples (Table 6). Peters et al. (2005) proposed a formula for calculating the equivalent vitrinite reflectance of a special sample using MPI-1 (Fig. 10). According to Table 6 and Peter's formula,

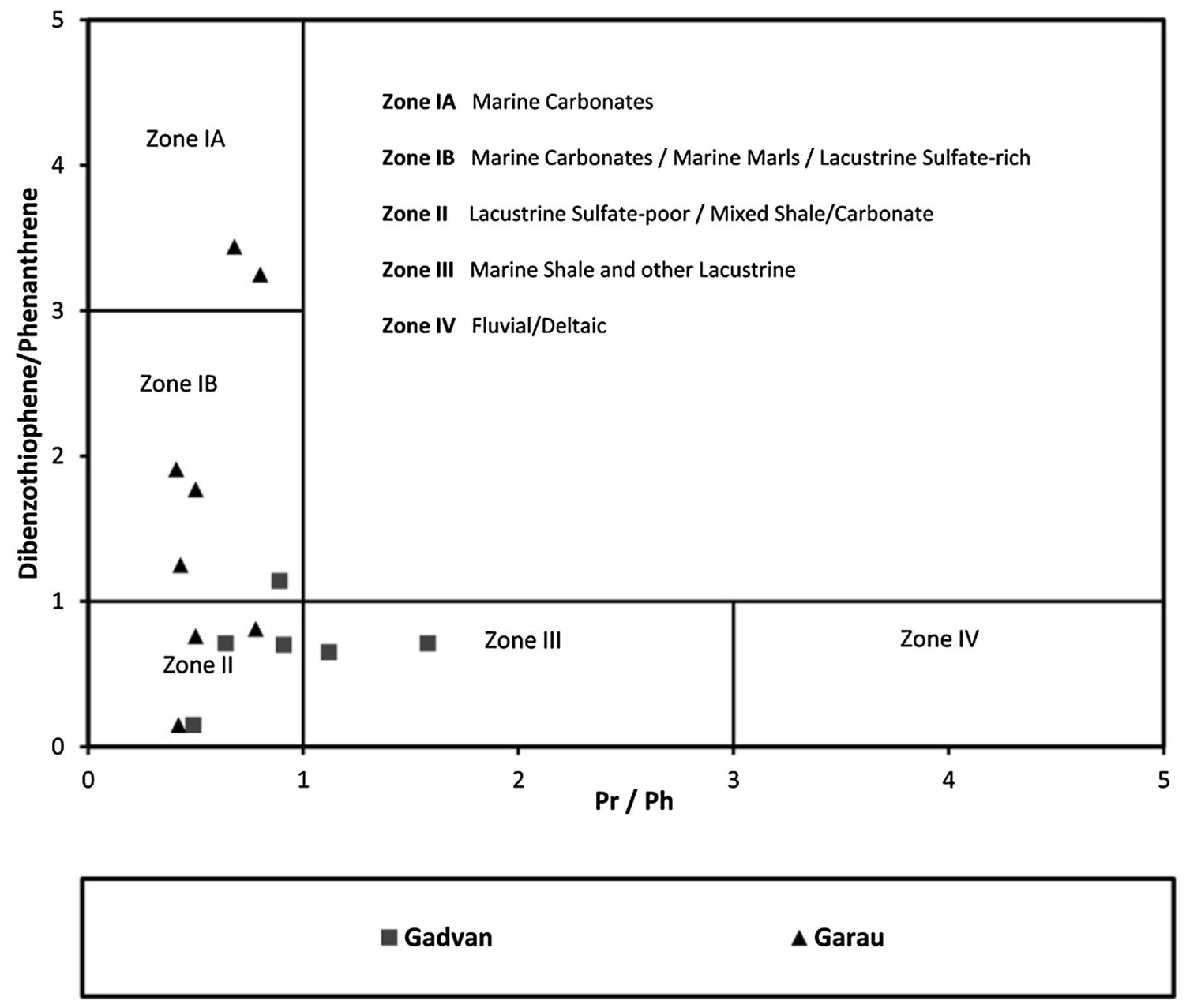

Fig. 11 Plot of $\mathrm{DBP} / \mathrm{Phen}$ versus $\mathrm{Pr} / \mathrm{Ph}$, showing a depositional environment of organic matter in the studied samples 


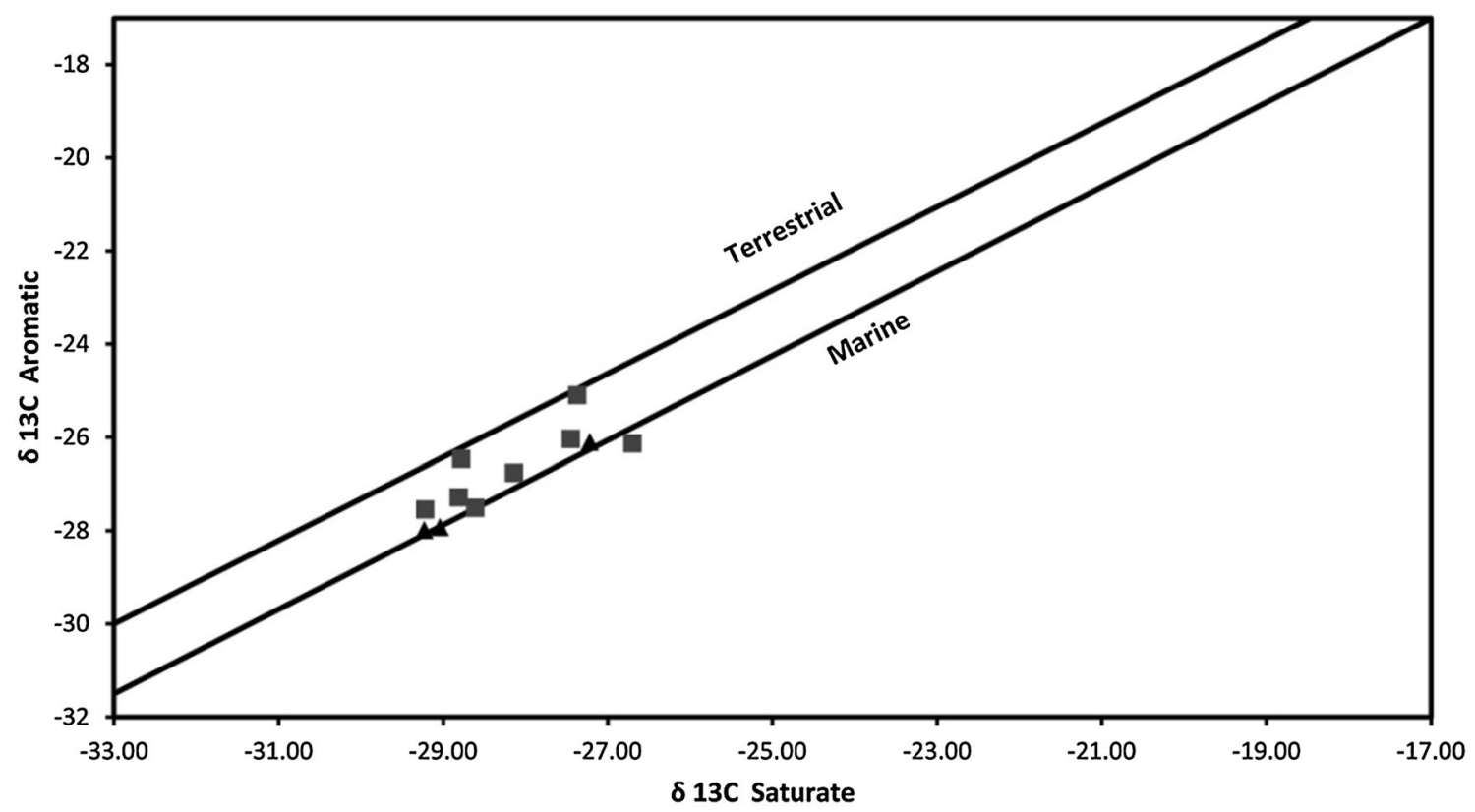

- Gadvan

$\Delta$ Garau

Fig. 12 Plot of $\delta^{13} \mathrm{C}$ aromatic versus saturate values to investigate organic matter depositional environment (Sofer 1984)

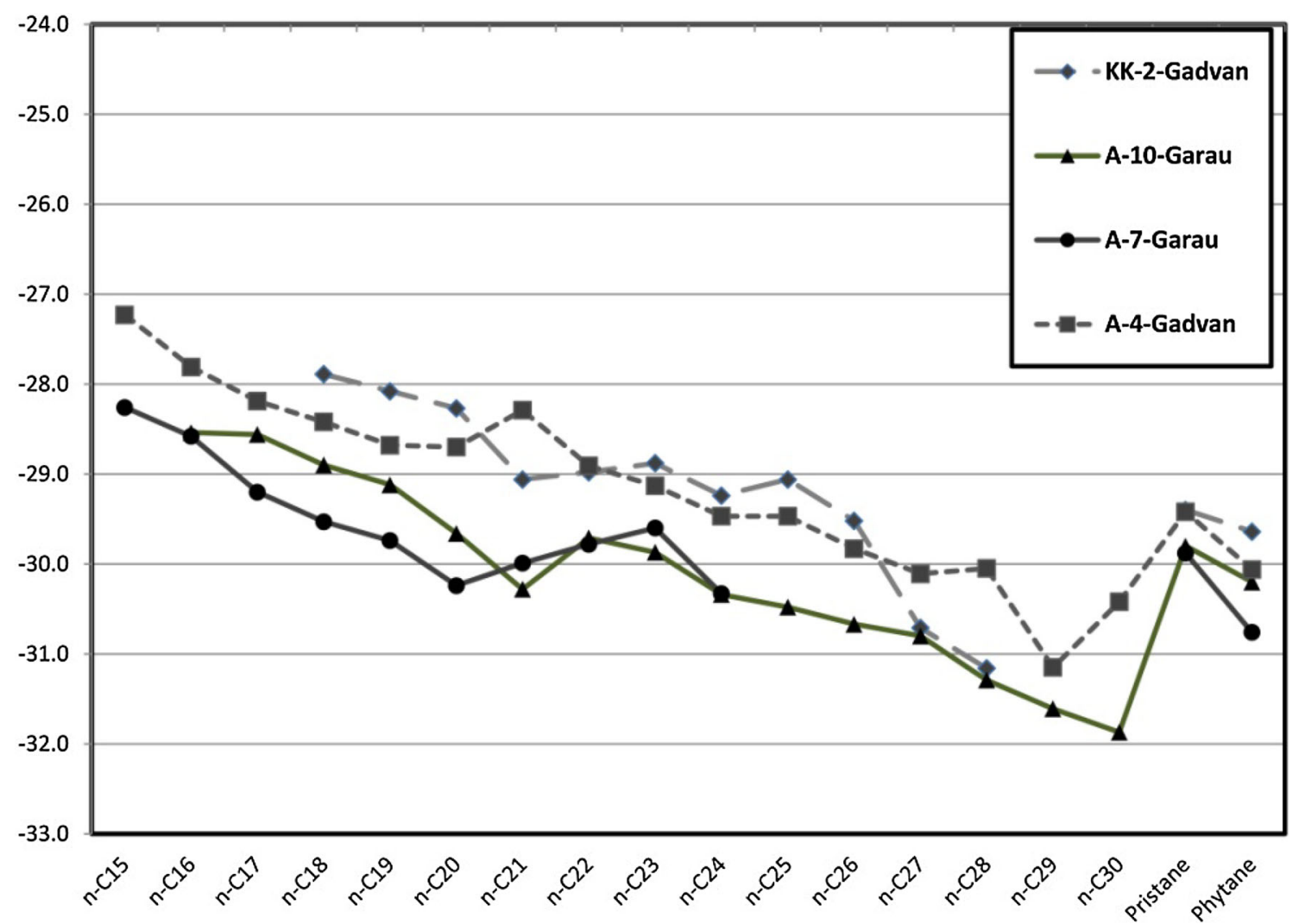

Fig. 13 Plot of n-alkanes GC-IRMS profile for four samples in the Gadvan and Garau formations; two different profiles are obvious. Also, Garau profiles are lighter in n-alkane isotope value 
the average calculated vitrinite reflectance in the Gadvan and Garau formations are 0.75 and $0.84 \%$, respectively.

Regarding biomarkers more specifically related to the environment of deposition, Table 6 shows the relative proportion of the $\mathrm{C}_{27}-\mathrm{C}_{28}$ and $\mathrm{C}_{29}$ regular steranes. Higher $\mathrm{C}_{27}$ values for the Garau samples indicate a marine depositional environment. By contrast, higher $\mathrm{C}_{28}$ values for the Gadvan Formation mean the input of terrestrial organic matter (Hunt 1996; Mackenzie et al. 1983). Total/NIOC (2003) in a joint study showed that, with the increasing age of source rock, the amount of $\mathrm{C}_{28}$ regular steranes in the samples decreases. They introduced a table to use the amount of $\mathrm{C}_{28}$ regular steranes as indicators of the age of an specific oil in the Persian Gulf. In this study, the $\mathrm{C}_{28}$ regular sterane content of both the Gadvan and the Garau has the similar average values, 27.33 and $27.25 \%$, respectively, which can be used to further source-oil correlation.

A cross-plot of DBT/Phen versus $\mathrm{Pr} / \mathrm{Ph}$ can be used to detect the depositional environment of organic matter (Hughes et al. 1995). As indicated in Fig. 11, the Gadvan Formation is located in a mixed shale/carbonate environment, and the Garau Formation is located in a marine carbonate depositional environment.

Abeed et al. (2011), using visual kerogen interpretation and biomarker data, reported kerogen Type II-S for the Sulaiy Formation (time equivalent of the Garau Formation), which is in agreement with the high concentration of dibenzothiophene (strongly anoxic marine environment) compound in the Garau Formation.

\section{Isotope study}

In this study, bulk composition stable carbon isotope analysis was applied to determine the depositional environment of the Gadvan and Garau formations (Table 5). Moreover, individual n-alkanes GC-IRMS were measured to differentiate the source rock for future oil-source correlation. As Fig. 12 shows with a plot of $\delta^{13} \mathrm{C}$ aromatic versus $\delta^{13} \mathrm{C}$ saturates (Sofer 1984), the Gadvan samples originated in a marine environment with terrestrial influences, while the Garau samples derived from a marine environment.

Regarding Table 5, the canonical variable (CV) confirms the result because, for all the Garau Formation samples, the CV is less than 0.47 , while of the 8 analyzed samples from the Gadvan Formation, 5 have $\mathrm{CV}$ values more than 0.47 (Sofer 1984).

GC-IRMS analysis, in which carbon isotopic ratios were measured on specific saturated hydrocarbons, is shown in Table 7. As illustrated in Fig. 13, two different n-alkane isotope profiles for the Gadvan and Garau formations emerged, in which the Garau Formation profile is more 
negative and $\delta^{13} \mathrm{C}$ for individual $\mathrm{n}$-alkanes is systematically lower than in the Gadvan samples. This obvious difference in the isotope value was not seen in bulk isotope data in Table 5 and Fig. 12. Hayes (1993) stated that more negative isotope values indicate more planktonic algae.

\section{Conclusion}

Results of Rock-Eval analysis indicate that the Gadvan Formation, with an average TOC of $0.65 \%$ and $\mathrm{HI}$ values of $122 \mathrm{mgHC} / \mathrm{g}$ TOC, can be classified as marginal source rock; by contrast, the Garau Formation, with TOC and HI current values up to $5.72 \%$ and $413 \mathrm{mgHC} / \mathrm{g}$ TOC, respectively, should be considered as having good to excellent source potential. Moreover, it should be recalled that the initial TOC and HI values of the Garau samples were both significantly higher than the current values. The kerogen type in the Gadvan Formation is mainly Type III with some input of Type II, and, as Fig. 4 shows, the kerogen is of Type II in the Garau Formation.

Gadvan samples are situated between 3510 and $4525 \mathrm{~m}$ depth. These samples are immature or at the beginning of the oil window, but have not yet reached the expulsion window (average $T_{\max }=433{ }^{\circ} \mathrm{C}$, average $\mathrm{VR}_{0}=0.67 \%$ ). It is understood that in the synclinal part of the Abadan plain, the Gadvan may have reached the expulsion window. However, as the Gadvan Formation contains a limited amount of Type III kerogen, the contribution of the Gadvan on the charge of Abadan Plain hydrocarbon reserves is deemed negligible. By contrast, Garau samples came from a current burial ranging from 4250 to $5239 \mathrm{~m}$ (with the exception of Haftkel oil field, where more than $1000 \mathrm{~m}$ of Aghajari layers were eroded prior to the Zagros Folding) and are already in the peak of oil expulsion, or already at the beginning of the gas and condensate stage (average $T_{\max }=441{ }^{\circ} \mathrm{C}$, average $\mathrm{VR}_{0}=0.82 \%$ ). Again, maturity is higher in the deeper part of the Abadan Plain. At Haftkel, Garau is shallower, 3300-4250 m, and no vitrinite reflectance were measured. However, the average $T_{\max }$ of $441{ }^{\circ} \mathrm{C}$ confirms the importance of the erosion of the Aghajari Formation.

GC parameters for the Gadvan Formation indicate high land plant contribution, low maturity, and an oxic to suboxic depositional environment of organic matter. In the Garau Formation, an advanced level of thermal maturity, Type II (likely II-S) organic matter, and a marine depositional environment under anoxic condition have been recognized.

Saturate and aromatic biomarker parameters, as well as isotopic analysis, confirm the Rock-Eval and GC results. In the Gadvan Formation, a maturity level of early oil generation (MPI-1 suggests equivalent $\mathrm{VR}_{0} \approx 0.75$ ) and mixed shale/carbonate with terrigenous input depositional environment $(\mathrm{CV}>0.47)$ has been established, while, for the Garau Formation, a high level of maturity (MPI-1 suggests equivalent $\left.\mathrm{VR}_{0} \approx 0.84\right)$ and marine carbonate depositional environment $(\mathrm{CV}<0.47)$ has been determined.

GC-IRMS analysis results show two different n-alkane isotope profiles where the Garau Formation profile is more negative, which shows more planktonic algae and higher maturity. These n-alkane isotope profiles can be used for further oil-source correlation in ongoing studies.

The excellent, mature Garau source rocks in the Abadan Plain area have generated huge amounts of oil, and possibly gas and condensate, which were ready to be trapped in the large $\mathrm{N}-\mathrm{S}$ oriented anticlines, such as Azadegan, Hosseinieh, Darquain and Mahshahr, which were formed well before the Zagros Folding.

Acknowledgements The author would like to offer sincere thanks to the National Iranian Oil Company-Exploration Directorate (NIOCEXP) for providing samples, data and financial support of geochemical analysis. We also are grateful to the Geochemistry Department of NIOC-EXP, especially for helpful discussions and comments which improved the original manuscript.

Open Access This article is distributed under the terms of the Creative Commons Attribution 4.0 International License (http:// creativecommons.org/licenses/by/4.0/), which permits unrestricted use, distribution, and reproduction in any medium, provided you give appropriate credit to the original author(s) and the source, provide a link to the Creative Commons license, and indicate if changes were made.

\section{References}

Abdollahie Fard I, Braathen A, Mokhtari M, Alavi SM (2006) Interaction of the Zagros Fold-Trust Belt and the Arabian-type, deep seated folds in the Abadan Plain and the Dezful Embayment, SW Iran. Pet Geosci 46:347-362

Abeed Q, Alkhafaji A, Littke R (2011) Source rock potential of the upper Jurassic-Lower Cretaceous succession in the southern Mesopotamian basin, southern Iraq. J Pet Geol 34(2):117-134

Alavi M (2007) Structures of the Zagros fold thrust belt in Iran. Am J Sci 307:1064-1095

Alizadeh B, Sarafdokht H, Rajabi M, Opera A, Janbaz M (2012) Organic geochemistry and petrography of Kazhdumi (AlbianCenomanian) and Pabdeh (Paleogene) potential source rocks in southern part of the Dezful Embayment, Iran. Org Geochem 49:36-46

Aqrawi AAM, Goff JC, Horbury AD, Sadooni FN (2010) The petroleum geology of Iraq. Scientific press, Beaconsfield

Bjorøy M, Hall K, Hall PB, Leplat P (1992) Detailed hydrocarbon analyser for well site and laboratory use. Mar Pet Geol 9:648-665

Bordenave ML, Burwood R (1990) Source rock distribution and maturation in the Zagros orogenic belt, provenance of the Asmari and Sarvak reservoirs oil accumulations. Org Geochem 16:369-387

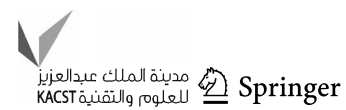


Bordenave ML, Hegre JA (2010) Current distribution of oil and gas fields in the Zagros Fold Belt of Iran and contiguous offshore as the result of the petroleum systems. Geol Soc Lond Spec Publ 330:291-353

Bordenave ML, Huc AY (1995) The Cretaceous source rocks in the Zagros foothills of Iran: an example of a large size intra-cratonic basin. Revue de l'Institut Français du Pétrole 50:527-753

Espitalié J, Bordenave ML (1993) Screening techniques for source rocks evaluation; tools for source rocks routine analysis; RockEval pyrolysis. In: Bordenave ML (ed) Applied Petroleum Geochemistry, Editions Technip, Paris, France, pp 273-261

Espitalié J, Laporte JL, Madec M, Marquis F, Leplat P, Paulet J (1977) Méthoderapide de caractérisation des rochesmères, de leur potential pétrolieret de leur degree d'évolution. Revue de l'InstitutFrançais du Pétrole 32:23-45

Fakour I, Jahani D, Asilian Mahabadi H (2010) Facies, Depositional environment and sequence stratigraphy of the Gadvan and Dariyan formations in north of Dezful Embayment in Izeh ZoneZagros Basin. In: The 1st international applied geological congress, Mashhad, Iran

Falcon NL (1967) The geology of the northeast margin of the arabian basement shield. Adv Sci 24:31-42

Hayes JM (1993) Factors controlling the 13C content of sedimentary organic compounds; principle and evidence. Mar Geol 113:111-125

Hughes WB, Holba AG, Dzou LIP (1995) The ratio of dibenzothiophene to phenanthrene and pristane to phytane as indicator of depositional environment and lithology of petroleum source rock. Org Geochem 17:3581-3598

Hunt JM (1996) Petroleum geochemistry and geology, 2nd edn. W.H. Freeman and Company, New York

James GA, Wynd JG (1965) Stratigraphic nomenclature of Iranian oil consortium agreement area. AAPG Bull 49(12):2182-2245

Jassim SZ, Goff HC (2006) Geology of Iraq. Dolin, Prague and Moravian Museum, Brno

Kent P, Slinger FCP, Thomas AN (1951) Stratigraphical exploration surveys in the Persia. In: Third petroleum congress. The Hague, section 1, pp 141-161

Mackenzie AS, Li RW, Maxwell JR, Moldowan JM, Seifert WK (1983) Molecular measurement of thermal maturation of Cretaceous shales from the Overthrust belt Wyoming, USA. In: Bjoroy M et al (eds) Advanced in organic geochemistry 1981. Wiley, New York, pp 496-503

Mashhadi ZS, Rabbani AR (2015) Organic geochemistry of crude oils and Cretaceous source rock in the Iranian sector of the Persian Gulf; an oil-oil and oil-source rock correlation study. Int J Coal Geol 146:118-144

Mashhadi ZS, Kamali MR, Rabbani AR (2014) Source rock evaluation and geochemical characterization of Albian
Kazhdumi Formation offshore SW Iran. In: Third EAGE exploration workshop, 6-9 April 2014, Abu Dhabi, UAE

Moldowan JM, Seifert WK, Gallegos EJ (1985) Relationship between petroleum composition and depositional environment of petroleum source rock. AAPG Bull 69(8):1255-1268

Moldowan JM, Sundararaman P, Schoell M (1986) Sensitivity of biomarker properties to depositional environment and/or source input in the Lower Toarcian of S.W. Germany. Org Geochem 10:915-926

Motiei H (1995) Petroleum geology of Zagros. Publication of the Geological Survey of Iran (in Persian)

Muris RJ (1980) Middle East stratigraphic evolution and oil habitat. Am Assoc Pet Geol Bull 64:597-618

Peters KE, Cassa MR (1994) Applied source rock geochemistry. In: Magoon LB, Dow WG (eds) The petroleum system-from source to trap, vol 60. American Association of Petroleum Geologists Memoir, Tulsa, pp 93-120

Peters KE, Moldowan JM (1993) The biomarker guide. Interpreting molecular fossils in petroleum and ancient sediments. Prentice Hall, Upper Saddle River

Peters KE, Walters CC, Moldowan JM (2005) The biomarker guide. Biomarker and isotope in petroleum exploration and earth history, vol 2. University of Cambridge Press, Cambridge, pp 475-1155

Rabbani AR, Bagheri Tirtashi R (2010) Hydrocarbon source rock evaluation of the super-giant Ahwaz oilfield, SW Iran. Aust J Basic Appl Sci 4:673-686

Rabbani AR, Mashhadi ZS, Rezaei Z (2013) Source rock of the Barremian to Early Aptian Gadvan Formation in the Persian Gulf. Applied Geolgy 1(9):21-30 (in Persian)

Sepehr M, Cosgrove JW (2004) Structural framework of the Zagros Fold-Thrust Belt, Iran. Mar Pet Geol 21:829-843

Sofer Z (1984) Stable carbon isotope composition of crude oils; application to source depositional environment and petroleum alteration. AAPG Bull 68:31-49

Stocklin J (1974) Possible ancient continental margins in Iran. In: Burk CA, Drake CL (eds) The geology of continental margins. Springer, New York, pp 873-887

Taylor GH, Teichmüller M, Davis A, Diessel CFK, Littke R, Robert P (1998) Organic petrology. Gebrüder Borntraeger, Berlin

Tissot BP, Welte DH (1984) Petroleum formation and occurrence, 2nd edn. Springer, New York

Zeinalzadeh A, Moussavi-Harami R, Mahboubi A, Sajjadian VA (2015) Basin and petroleum system modeling of the Cretaceous and Jurassic source rock of the gas and oil reservoirs in Darquain field, south west Iran. J Nat Gas Sci Eng 26:419-426 